\title{
Targeting Cancer Metabolism - Revisiting the Warburg Effects
}

\author{
Quangdon Tran' ${ }^{1}$ Hyunji Lee', Jisoo Park', Seon-Hwan Kim² and Jongsun Park ${ }^{1}$ \\ 'Department of Pharmacology and Medical Science, Metabolic Diseases and Cell Signaling Laboratory, \\ Research Institute for Medical Sciences, College of Medicine, Chungnam National University, Daejeon, Korea \\ ${ }^{2}$ Department of Neurosurgery, Institute for Cancer Research, College of Medicine, \\ Chungnam National University, Daejeon, Korea
}

(Received March 15, 2016; Revised April 21, 2016; Accepted May 20, 2016)

\begin{abstract}
After more than half of century since the Warburg effect was described, this atypical metabolism has been standing true for almost every type of cancer, exhibiting higher glycolysis and lactate metabolism and defective mitochondrial ATP production. This phenomenon had attracted many scientists to the problem of elucidating the mechanism of, and reason for, this effect. Several models based on oncogenic studies have been proposed, such as the accumulation of mitochondrial gene mutations, the switch from oxidative phosphorylation respiration to glycolysis, the enhancement of lactate metabolism, and the alteration of glycolytic genes. Whether the Warburg phenomenon is the consequence of genetic dysregulation in cancer or the cause of cancer remains unknown. Moreover, the exact reasons and physiological values of this peculiar metabolism in cancer remain unclear. Although there are some pharmacological compounds, such as 2-deoxy-D-glucose, dichloroacetic acid, and 3-bromopyruvate, therapeutic strategies, including diet, have been developed based on targeting the Warburg effect. In this review, we will revisit the Warburg effect to determine how much scientists currently understand about this phenomenon and how we can treat the cancer based on targeting metabolism.
\end{abstract}

Key words: Energy metabolism, Warburg effects, Cancer metabolism, Mitochondria

\section{INTRODUCTION}

During the early $19^{\text {th }}$ century, Dr. Otto Warburg demonstrated the enhancement of $\mathrm{O}_{2}$ uptake and subsequent rapid cell division upon fertilization. He hypothesized that cancer cells might also take up more $\mathrm{O}_{2}$ than normal cells (1). However, subsequently, Warburg and his co-workers noticed that rat liver carcinoma did not take up more $\mathrm{O}_{2}$ than normal liver tissue, and that, even in the presence of $\mathrm{O}_{2}$, such tissue produced lactic acid $(2,3)$. In 1956, Warburg first reported that cancer cells exhibit high rates of glucose uptake and lactic acid production even in the presence of oxygen (4). It seemed that cancer cells preferred aerobic glycolysis to oxidative phosphorylation (OxPhos). Warburg also initially sus-

Correspondence to: Jongsun Park, Department of Pharmacology and Medical Science, Metabolic Diseases and Cell Signaling Laboratory, Research Institute for Medical Sciences, College of Medicine, Chungnam National University, Daejeon 35015, Korea E-mail: insulin@cnu.ac.kr

This is an Open-Access article distributed under the terms of the Creative Commons Attribution Non-Commercial License (http:// creativecommons.org/licenses/by-nc/3.0) which permits unrestricted non-commercial use, distribution, and reproduction in any medium, provided the original work is properly cited. pected that cancer cells displayed impaired respiration due to the functional defects in mitochondria (5), whereas the findings from his own laboratory (3) and those of others $(6,7)$ indicated otherwise. Although the observations of Chance and Weinhouse $(6,7)$ contradicted Warburg's argument of mitochondrial defects in cancers, many studies over the past several decades have documented oncogenic nuclear and mitochondrial DNA mutations in proteins involved in respiration. Moreover, remarkably, after more than half a century's research, the Warburg effect stands true for most types of cancer cells and has become the seventh hallmark of cancer cells besides the following: 1) persistent growth signals, 2) evasion of apoptosis, 3) insensitivity to antigrowth signals, 4) unlimited replicative potential, 5) angiogenesis, and 6) invasion and metastasis $(8,9)$. The exact reasons for, and physiological value of, atypical metabolism in cancer remain to be elucidated. People generally believe that the Warburg effect will confer growth advantages on tumor cells, including the provision of faster production of ATP, amino acids for protein synthesis, nucleic acids for DNA duplication, and lipids for cell bio-membrane synthesis that might be needed in cell proliferation, as well as generate an acidic environment, which is harmful to normal cells but has no effect on tumor cells (10), and produce less 
reactive oxygen species (ROS) so that the genome of cancer cells may elude damage by a high concentration of ROS, resulting in apoptosis resistance in tumor subjects $(11,12)$. Currently, the Warburg effect and its causes have caught the attention of scientists because people believe that a better understanding of the mechanisms of the Warburg effect might ultimately lead to more effective treatments for cancer. Indeed, numerous publications have proposed different models; thus, a comprehensive and clear cause of the Warburg effect might be on the horizon. Moreover, some anti-cancer drugs have also been developed as applications of the switch from oxidative phosphorylation to glycolytic metabolism in cancer (13), besides the diagnosis and detection of metastasis using F-18 fluorodeoxyglucose (FDG) positron emission tomography (PET).

1. Relationship between tumor-specific glucose metabolism and genetic changes. When normal differentiated tissues are in the presence of oxygen, one glucose molecule can generate up to 36 ATP molecules. Glycolysis is the primary metabolic pathway in the cytoplasm that converts glucose to two pyruvate molecules. This process releases two ATP and two reduced nicotinamide adenine dinucleotide (NADH) molecules. Pyruvate is then transported to the mitochondria and is converted to an acetyl group that comes along with coenzyme A to form the acetyl-CoA complex. Acetyl-CoA then joins the Krebs cycle in the mitochondrial matrix. The net result is one ATP, three NADH and one reduced flavin adenine dinucleotide $\left(\mathrm{FADH}_{2}\right)$. The electron transport chains (I, II, III, IV) are electron transporters inserted into the inner mitochondrial membrane that transport electrons from NADH and $\mathrm{FADH}_{2}$ to oxygen. In the pathway, protons are impelled from the mitochondrial matrix to the intermembrane space, and oxygen is the final acceptor for conversion to water molecules. Regarding oxygen reduction, ROS are produced in complex I, II, and III (14). The energy is deposited in the form of a proton gradient between the intermembrane space and matrix, and the energy will finally be converted to ATP (15). The completed process results in the yield of 36 ATP molecules. However, under conditions where oxygen is limited, glucose undergoes anaerobic metabolism, which is the partial oxidation of glucose to pyruvate, and is reduced to lactate (in human) or alcohol (in bacteria). NADH becomes oxidized, and 1$\mathrm{NAD}^{+}$is regenerated for glycolysis. Only two ATP molecules are yielded in anaerobic metabolism. Interestingly, the Warburg effect results in atypical metabolism, indicating that cancer cells mostly convert glucose into lactate even in the presence of oxygen. This characteristic is shared with normal proliferating cells. The net energy yield in anaerobic glycolysis is two ATP molecules, whereas the yield in oxidative phosphorylation is thirty-six. This observation leads to the paradox: why is the pathway that produces less ATP selected in such high-demand cells and is the Warburg effect the consequence of genetic changes in cancer or the cause of cancer? As mentioned above, a very common characteristic of cancer cells described by Otto Warburg is that the cancer cell exhibits increased glycolytic metabolism compared with normal cells. Using the dbEST database for the expression of genes and expressed sequence tags [U.S. NCBI, National Institutes of Health (16)], it was found that genes involved in glycolysis are overexpressed in 24 different types of cancers, representing more than $70 \%$ of all human cancer cases (17). Although the key factors/pathways underlying the cancer metabolic phenotype remain to be elucidated, several mechanisms have been proposed base on the epigenetic changes in proto-oncogenes and tumor suppressor genes in the multistep process of carcinogenesis. In this session, we classified those mechanisms into 4 types: 1) mitochondrial changes - defect in oxidative phosphorylation, 2) changes in the metabolome or metabolite pools that facilitate glycolytic flux, 3) hypoxiainduced switch from oxidative mitochondrial respiration to glycolysis and 4) coordinated regulation of proteins that control glycolytic flux.

1-1. Mitochondrial changes-defect in oxidative phosphorylation: Otto Warburg had mentioned that respiration must be defective in cancers because high levels of $\mathrm{O}_{2}$ cannot suppress the production of lactic acid by cancer cells $(18,19)$. Thus, are mitochondrial defects sufficient and necessary for tumorigenesis? With the discoveries of oncogenic mutations in mitochondrial metabolic enzymes, it is now untenable to deny the role of mitochondria in tumorigenesis (20,21). Indeed, cancer cell mitochondria were reported to show a reduction in DNA, a lower transcription rate and an accumulation of genomic mutations and deletions (Table 1). Mutation in certain mitochondrial genes may disrupt the electron transport chains, thereby decreasing oxidative phosphorylation. The mitochondrial genome is particularly susceptible to mutation for several reasons. Electrons may escape or leak from electron transport complexes, mainly at complexes I and III, to react with molecular oxygen, forming superoxide radicals $\left(\mathrm{O}_{2}^{-}\right)$and other reactive oxygen species that damage mitochondrial DNA. Mitochondrial DNA is supercoiled, circular and prone to breakage. Moreover, there are few repair mechanisms for mitochondrial DNA.

1-1-1. Succinate dehydrogenase (SDH) and fumarate hydratase (FH); SDH is involved in the TCA cycle, catalyzes the conversion from succinate to fumarate, and releases one molecular-reduced flavin adenine dinucleotide. SDH mutations are commonly found in paraganglioma, gastric stromal tumors, and childhood T-cell acute leukemia (22,23). Germline mutations in SDH seem to be closely associated with human head and neck paragangliomas (23). These facts suggest that SDH mutations may provide a growth advantage in the initial stages of tumorigenesis. $\mathrm{FH}$, an enzyme similar to $\mathrm{SDH}$, also catalyzes the reaction from 
Table 1. Mitochondrial genetic changes in cancers

\begin{tabular}{|c|c|c|}
\hline Cancer Type & Mitochondrial Changes & Percentage of Cases \\
\hline Colorectal cancer & $\begin{array}{l}\text { 12S rRNA, } 16 \mathrm{~S} \text { rRNA, ND1, ND4L, ND5, Cytochrome b, COX I, COX II } \\
\text { and COX III genes. } \\
\text { Most are } \mathrm{T} \rightarrow \mathrm{C} \text { or } \mathrm{G} \rightarrow \text { A transitions }\end{array}$ & $70 \%$ \\
\hline Ovarian cancer & $\begin{array}{l}\text { D-loop, 12S rRNA, 16S rRNA and cytochrome b mutation. } \\
\text { Most are } \mathrm{T} \rightarrow \mathrm{C} \text { or } \mathrm{G} \rightarrow \mathrm{A} \text { transitions }\end{array}$ & $60 \%$ \\
\hline \multirow[t]{2}{*}{ Breast cancer } & Mutations in the D-loop region of mitochondrial genome & $60 \%$ \\
\hline & 16S rRNA, ND1, ND2, ND4, ND5, Cytochrome b and ATPase 6 & $<15 \%$ \\
\hline Hepatocarcinoma & Mutations in the D-loop & Frequent \\
\hline \multirow[t]{2}{*}{ Gastric cancer } & Deletion of mtDNA & $54 \%$ \\
\hline & Insertions/deletions in the D-loop region or transitions in ND1, ND5 and COX I & $44 \%$ \\
\hline $\begin{array}{l}\text { Esophageal } \\
\text { adenocarcinomas or } \\
\text { Barrett's esophagus }\end{array}$ & D-loop alterations & $40 \%$ \\
\hline Esophageal carcinoma & D-loop mutation & $5 \%$ \\
\hline \multirow[t]{3}{*}{ Renal cell carcinoma } & A 264-bp deletion of the ND1 & $100 \%$ \\
\hline & Loss of mtDNA and mRNA coding for subunit the ND3 gene & - \\
\hline & Loss of ATP synthase activity in Complex V & $100 \%$ \\
\hline $\begin{array}{l}\text { Pancreatic cancer cell } \\
\text { lines }\end{array}$ & $\begin{array}{l}12 \mathrm{~S} \text { rRNA, } 16 \mathrm{~S} \text { rRNA, ND1, ND2, COX I, COX II, ATPase 6, COX III, } \\
\text { ND4, ND4L, ND5, ND6, Cytochrome b as well as the non-coding D-loop } \\
\text { region. } \\
\text { Also 6-fold to 8-fold increase in the mtDNA mass. }\end{array}$ & $100 \%$ \\
\hline Prostate cancer & D-loop region, 16S rRNA and NADH subunit & $18.75 \%$ \\
\hline Brain tumors & mtDNA highly amplified & $87 \%$ \\
\hline Thyroid cancer & $\begin{array}{l}\text { mtDNA alterations in the genes coding for Complex I and comlex IV of the } \\
\text { respiratory chain }\end{array}$ & $\begin{array}{l}\text { the mtDNA common } \\
\text { deletion was identified in } \\
100 \% \text { of Hurthle cell } \\
\text { tumors, } 33.3 \% \text { of adenomas, } \\
\text { and in } 18.8 \% \text { of non-Hurthle } \\
\text { cell papillary carcinomas. }\end{array}$ \\
\hline $\begin{array}{l}\text { Hematologic } \\
\text { malignancies }\end{array}$ & $\begin{array}{l}\text { Described mutations in cytochrome b, cytochrome c oxidases I and II and } \\
\text { ATPase } 8 \text {; increased mutations in the mitochondrially-encoded COX I and } \\
\text { COX II genes }\end{array}$ & - \\
\hline
\end{tabular}

ND - mitochondrially encoded NADH dehydrogenase; COX I-III - cytochrome oxidase subunit I-III; mtDNA - mitochondrial DNA; rRNA - ribosomal RNA; NADH - reduced form of nicotinamide adenine dinucleotide (Adapted from (9)).

fumarate to malate. $\mathrm{FH}$ mutations have been observed in several types of malignant tumors in different tissues and organs, such as uterine leiomyomatosis, cerebral cavernomas, and breast cancer (24). Mutations in SDH and FH promote increased levels of succinate and fumarate, which inhibit prolyl hydroxylases that are responsible for the $\mathrm{O}_{2}-$ dependent modification of hypoxia inducible factor- $1 \alpha$ (HIF-1 $\alpha)$ and its degradation. In this regard, HIF-1 $\alpha$ needs to be hydroxylated by proline hydroxylases (PHDs), a family of $\alpha$-ketoglutarate $(\alpha-K G)$-dependent enzymes before undergoing degradation under normal oxygen conditions $(25,26)$. During the process of HIF-1 $\alpha$ hydroxylation, the substrate of $\alpha-\mathrm{KG}$ is oxidized, with the generation of succi- nate as a product (27). Moreover, subsequent tests verified that fumarate could inhibit PHD2 (28), while succinate could reduce the enzymatic activity of PHD3 (29). Therefore, even in the presence of normal levels of $\mathrm{O}_{2}$, these mutations are thought to constitutively increase the production of HIF-1 $\alpha$ to levels that trigger tumorigenesis (29). HIF activation under non-hypoxic conditions would thus inhibit the Pasteur effect and induce the Warburg effect in cancer cells. HIF consists of two subunits: an $\alpha$ subunit usually located in the cytoplasm (HIF-1 $\alpha$ ) and a $\beta$ subunit located in the nucleus (HIF-1 $\beta$ ). The inhibition of PHD promotes HIF- $1 \alpha$ to enter into the nucleus and integrate with HIF-1 $\beta$ to form heterodimers, thus promoting the expression of a 
series of HIF target genes, including genes encoding glucose transporters (GLUTs) (30), glycolysis enzymes such as pyruvate dehydrogenase kinase (PDK) (31,32), lactate dehydrogenase A (LDH-A), and myc (33). The enhancement of these HIF-target genes synergistically promotes the Warburg effect, allowing cancer cells to gain growth advantages $(29,34,35)$.

1-1-2. P53, ATPase inhibitor protein (IF1) and isocitrate dehydrogenase (IDH); A nuclear gene that regulates mitochondrial respiration is the tumor suppressor p53 (TP53, also known as p53)-inducible gene synthesis of cytochrome $\mathrm{c}$ oxidase-2 (SCO2) (36). SCO2 is critical for regulating the cytochrome c oxidase (COX) complex, the major site of oxygen utilization in oxidative phosphorylation. SCO2 connects p53 to mitochondrial respiration and is responsible for the Warburg effect (36). Another possible mechanism for decreased oxidative phosphorylation is the overexpression of the ATPase inhibitor protein (IF1) (37). A decrease in $\mathrm{H}^{+}$-ATP synthase ( $\beta$-F1-ATPase) is a proteomic signature of decreased oxidative phosphorylation and characteristic of cancer cell bioenergetics, which can predict the prognosis of colon, lung, and breast cancer. The level of this protein is inversely correlated with the glycolytic rate in cancer cells (38). When oxidative phosphorylation becomes inefficient or defective, the loss of mitochondrial ATP removes the inhibition on glycolysis, providing a compensatory mechanism to generate ATP. In addition to the familial cancer syndromes associated with OxPhos mutations, somatic mutations of IDH1 (cytosolic form) and IDH2 (mitochondrial form) have been shown in low-grade gliomas and normal acute myelogenous leukemia $(20,39,40)$. The catalytic inactive form of IDH1 and IDH2 was initially believed to cause the loss of function that led to diminished conversion of isocitrate to $\alpha$-ketoglutarate, a metabolic intermediate that is required for the degradation of HIF-1 $\alpha$ or HIF2 $\alpha$ (also known as EPAS1) (41). However, the stabilization of HIF$1 \alpha$ by mutant IDH1 or IDH2 has not been independently confirmed. Despite the loss of oxidative phosphorylation, the mitochondria remain essential in the processing of intermediate metabolites for various pathways involving carbohydrates, amino acids and fatty acids. Cancer cells depleted of mitochondrial DNA by treatment with ethidium bromide (42) continue to maintain mitochondrial mass. Moreover, a recent study demonstrated that cancer development and metastasis require mitochondria DNA (43).

1-2. Changes in the metabolome or metabolite pools that facilitate glycolytic flux: Fructose 2,6-bisphosphate is an important metabolite that stimulates glycolysis by a potent positive allosteric effect on PFK-1 and inhibits gluconeogenesis by blocking fructose 1,6-bisphosphatase (FBPase1) (44). The p53-inducible enzyme TP53-induced glycolysis and apoptosis regulator (TIGAR) is a FBPase-2 that functions to lower fructose 2,6-bisphosphate levels, thereby inhibiting glycolysis by decreasing the activity of PFK-1 and enhancing the activity of FBPase-1 (45). Because FBPase1 activity is reduced in many tumor cells (often due to the loss of p53 function and the resultant downregulation of TIGAR expression $(45,46))$, the fructose 1,6-bisphosphate level remains persistently elevated, and the "brake" on glycolysis is removed. However, the levels of TIGAR expression in various cancer types have not been examined. Nevertheless, fructose 1, 6-bisphosphate may be the key metabolite that increases the activity of PKM2, leading to a drastic increase in forward flux through glycolysis. Three other characteristics of the metabolome restricting glycolysis are the accumulation of pyruvate, accumulation of reduced hydrogen, and depletion of $\mathrm{NAD}^{+}$as glycolysis proceeds. Increased glycolysis alters the glycerol-3-phosphate and malate-aspartate shuttles, reducing the transport of $\mathrm{H}^{+}$into the mitochondrial intermembrane space and requiring the cancer cells to oxidize $\mathrm{NADH}$ to regenerate $\mathrm{NAD}^{+}$in the cytosol by LDH. c-MYC induces the increase in LDH type A (LDH-A) expression (47), and LDH-A, which converts pyruvate to lactate, plays a key role in carcinogenesis (48). The reduction in LDH-A using short hairpin RNAs stimulates oxidative phosphorylation and decreases the mitochondrial membrane potential. The tumorigenicity and ability to proliferate under hypoxia are decreased in LDH-A-deficient cells (48). The reduction in the transport of $\mathrm{H}^{+}$into the mitochondrial intermembrane space in cancer cells exhibiting the Warburg phenomenon also presents a challenge in intracellular $\mathrm{pH}(\mathrm{pHi})$ regulation. In normal cells, the $\mathrm{Na}^{+}$driven $\mathrm{Cl}^{-} / \mathrm{HCO}^{3-}$ exchanger (NHE1) and $\mathrm{Na}^{+}$-independent $\mathrm{Cl}^{-} / \mathrm{HCO}^{3-}$ exchanger are primarily responsible for the maintenance of pHi. In cancer cells, high NHE1 activity increases $\mathrm{pHi}$ and acidifies the extracellular space. The increased $\mathrm{pHi}$ facilitates glycolysis, and the resulting lactate is transported out of the cancer cells via the $\mathrm{H}^{+}$/lactate cotransporter (49). Other proteins involved in $\mathrm{pHi}$ regulation include the monocarboxylate carriers that transport bicarbonate anions and carbonic anhydrase. Carbonic anhydrase IX is a hypoxiainducible transmembrane protein and the only tumor-associated carbonic anhydrase isoenzyme known $(50,51)$; it is needed for the growth and survival of cancer cells under both normoxia and hypoxia (52).

1-3. Hypoxia-induced switch from oxidative mitochondrial respiration to glycolysis: The solid tumor microenvironment is characterized by a disorganized microvasculature (53), increased interstitial pressure (54) and the presence of hypoxic, a lack of oxygen zones (55). The absence of oxygen shuts down oxidative mitochondrial respiration, forcing the cancer cells to switch on glycolytic metabolism for bioenergy. The lack of mitochondrial ATP will remove the inhibition of PFK-1 and PKM2, leading to increased forward flux through glycolysis. PFKFB1-4 genes are responsive to hypoxia in vivo, indicating a physiological role for glycolysis in the adaptation to hypoxia (56). There is also evidence for the overexpression of a specific spliced iso- 
form of PFKFB-4 mRNA in cancer cells under hypoxic conditions (57). Overall, hypoxia activates HIF to induce adaptive responses, including angiogenesis, glycolysis, and $\mathrm{pH}$ regulation (58). The hypoxic microenvironment in which the cancer cells thrive may constitute a selection pressure to select for tumor cell clones with high glycolytic metabolism, as the cells evolve through the carcinogenic process (59).

\section{1-4. Coordinated regulation of proteins that control glycolytic flux:}

1-4-1. Regulation of cancer cell metabolism by the PKB; The PKB (Protein kinase B/Akt) signaling pathway has been shown to promote continued cell growth and coordinates the necessary metabolic changes to support cell growth by increasing glucose uptake, glycolysis and ATP production. Activation of PKB signaling may be a factor leading to the switch to glycolytic metabolism in cancer (52) (Fig. 1). PKB directly and/or indirectly regulates the transcription (60) and translation (61) of GLUT1, which functions in glucose uptake. PKB also activates hexokinase 2 (HK2) association with the mitochondria, promoting the phosphorylation of glucose to glucose 6-phosphate, to be metabolized via glycolysis or the pentose phosphate path- way, and the mitochondria-associated HK2 is involved in the inhibition of apoptosis $(62,63)$. Moreover, PKB regulates de novo fatty acid synthesis and the usage of fatty acid for $\beta$-oxidation. It phosphorylates ATP citratelyase (ACL), stimulating the cleavage of citrate to oxaloacetate and acetyl-coenzyme A (Ac-CoA) to supply downstream de novo fatty acid synthesis (64). Phosphoinositide 3-kinase (PI3K) and $\mathrm{PKB}$ suppress the expression of the $\beta$-oxidation enzyme carnitine palmitoyltransferase 1A (CPT1A), and the modulation of CPT1A expression by PI3K/PKB signaling is the mechanism to suppress $\beta$-oxidation during cell growth (65). The mammalian target of rapamycin (mTOR), a downstream effector of the $\mathrm{PI} 3 \mathrm{~K} / \mathrm{PKB}$ pathway, is situated at the crossroads of signaling pathways and is an integration center for signals bringing the coordinated regulation of nutrient uptake, energy metabolism, cell growth, proliferation, and cell survival $(66,67)$. mTOR is regulated by AMP-activated protein kinase (AMPK) (the cellular energy sensor), tuberous sclerosis $1 \& 2$ (TSC1-TSC2) complex, and Ras homolog enriched in brain (RHEB) (68). Most importantly, mTOR is an upstream activator of HIF-1 $\alpha$ in cancer cells (69), which is a subunit of a transcription factor that upregulates the expression of nearly all of the genes involved in

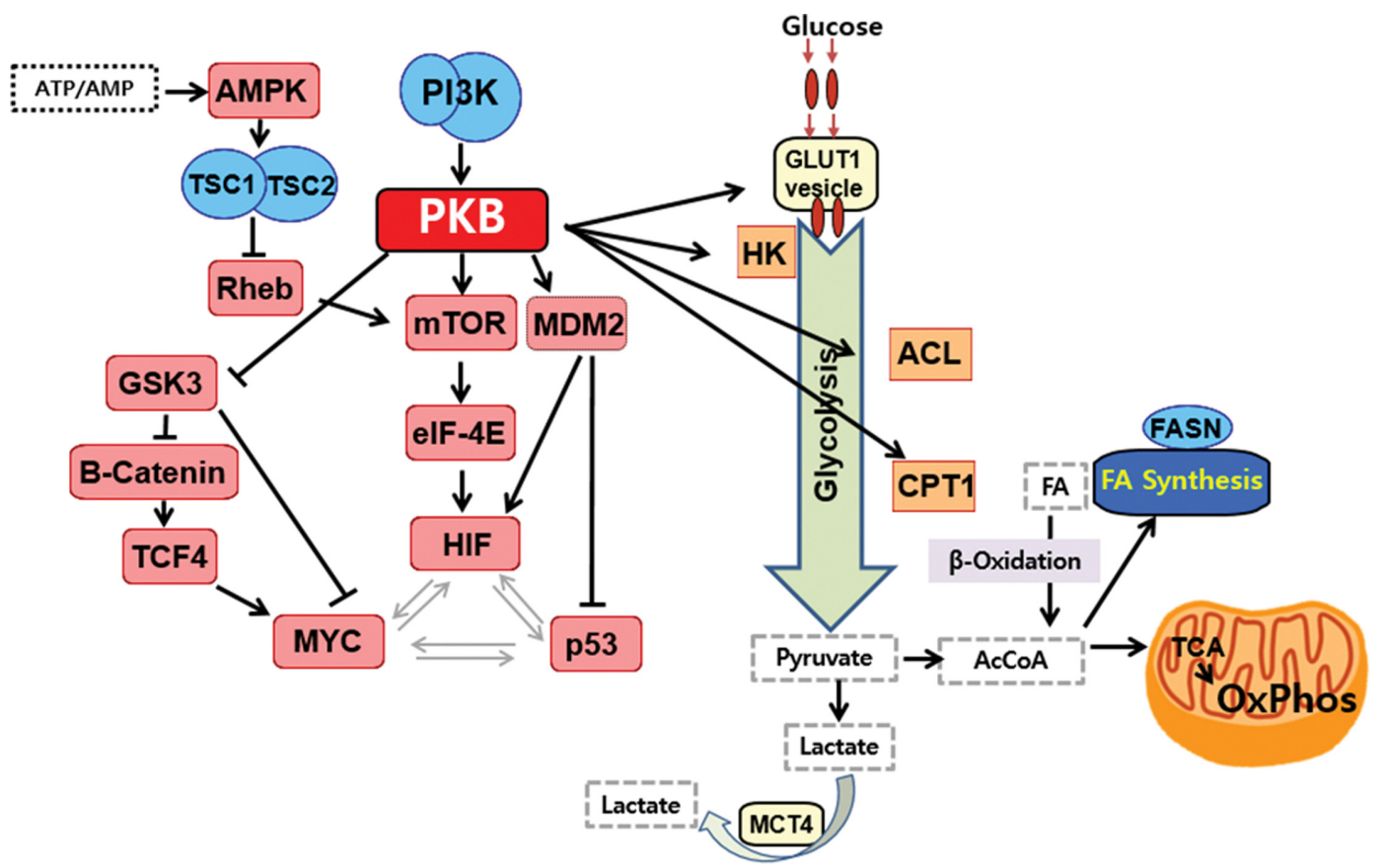

Fig. 1. The $\mathrm{PI} 3 \mathrm{~K} / \mathrm{PKB} / \mathrm{mTOR}$ signaling pathway regulates cancer cell metabolism. PKB upregulates glycolysis by affecting glucose transporter 1 (GLUT1) and activating hexokinase 2 (HK2) association with the mitochondria. Moreover, PKB regulates de novo fatty acid synthesis and the usage of fatty acid for $\beta$-oxidation. It phosphorylates ATP citratelyase (ACL) to supply downstream de novo fatty acid synthesis (64). Phosphoinositide 3-kinase (PI3K) and PKB suppress the expression of the $\beta$-oxidation enzyme carnitine palmitoyltransferase 1A (CPT1A), suppressing $\beta$-oxidation and impairing mitochondria. mTOR, a downstream effector of the PI3K/PKB pathway, is regulated by AMP-activated protein kinase (AMPK; the cellular energy sensor), the tuberous sclerosis 1 \& 2 (TSC1/TSC2) complex, and Ras homolog enriched in brain (RHEB). Most importantly, mTOR is an upstream activator of HIF-1 $\alpha$ in cancer cells (69), which is a subunit of a transcription factor that upregulates the expression of nearly all of the genes involved in the glycolytic pathway (See details in the text (Section 1-4-1)). Arrows represent stimulation/activation, and ends represent inhibition. 
the glycolytic pathway (32).

1-4-2. Regulation of glycolysis by a triad of transcription factors; Three transcription factors, c-MYC, HIF-1 and $\mathrm{p} 53$, regulate the flux of glucose through the glycolytic pathway (Fig. 2). The transport of glucose into cancer cells is controlled by glucose transporters, including GLUT-1, which are regulated by HIF-1. Hexokinases are important enzymes that regulate glycolysis, and HK2 is the isoform expressed specifically in skeletal muscle, adipocytes and cancer cells. HK2 regulates the first step in glycolysis (70). HK2 is regulated by p53 as well as HIF-1. The upstream regulatory element of the HK2 gene contains a carbohydrate response element (ChoRE) and response elements for protein kinase A, protein kinase C, HIF-1 and p53 (71,72). In cancer cells, the HK2 gene is amplified, activated, and induced by multiple signal transduction cascades, and the overexpressed HK2 binds to the outer membrane of mitochondria. HIF-1 is the major transcription factor regulating the transcription of most of the enzymes in the glycolytic pathway, from glucose to lactate (32) (Fig. 2). The promoter regions of the genes of these enzymes have been shown to have HIF-1 regulatory elements $(71,72)$. Pyruvate may also regulate the levels of glycolytic enzymes by preventing the oxygen-induced degradation of HIF- $1 \alpha$ protein, thus activating HIF-1 (73). The enzyme that is very important in regulating the pyruvate level is LDH-A, and the cis-acting elements of its gene promoter resemble the core of the ChoRE and E-box (5-CAGGTG-3), and they overlap with the consensus binding sites for both c-MYC and HIF-1. Increased activities of HIF-1 and/or c-MYC upregulate glycolytic enzyme genes, leading to an increased glycolytic capacity in cancer cells (71). Another enzyme regulated by HIF-1 and c-MYC is pyruvate dehydrogenase kinase-1 (PDK-1), which inhibits pyruvate dehydrogenase by phosphorylation, stopping the conversion of pyruvate to acetylCoA, thus depleting the fuel supply for oxidative phosphor-

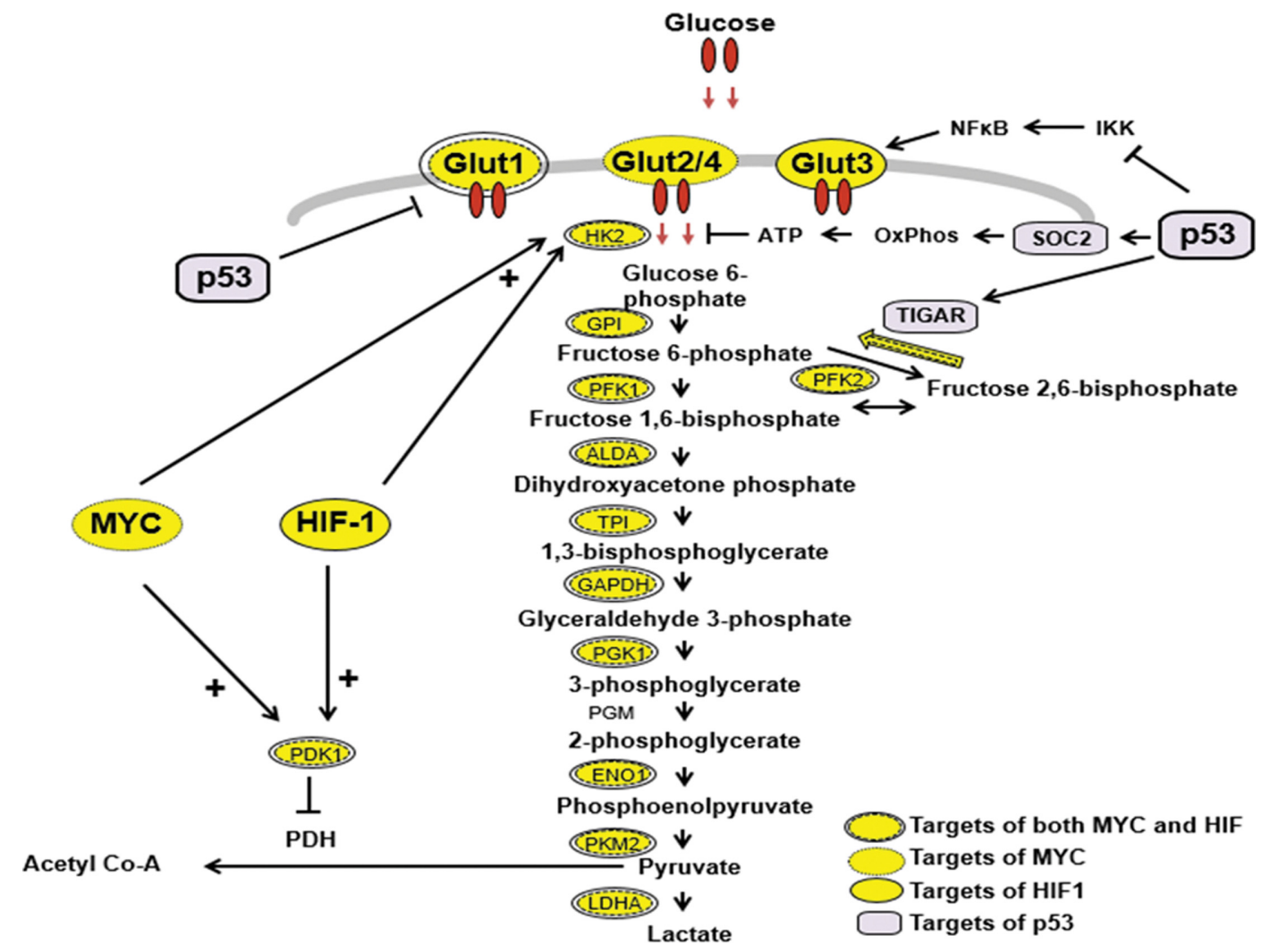

Fig. 2. c-MYC, HIF-1 and p53 regulate glycolytic metabolism. The Warburg phenomenon is due, at least in part, to the upregulation of genes coding for glucose transporters and glycolytic and regulatory enzymes mediated by the increased activity of the transcription factors c-MYC and HIF-1 in cancer cells, and the coordinated loss of regulatory proteins due to the loss of p53 function. Loss of p53 function also leads to the activation of GLUT-3 transcription via NFKB. Arrows represent stimulation/activation, and ends represent inhibition. + indicates synergism. HK2, hexokinase type 2; GPI, glucose phosphate isomerase; PFK1, phosphofructokinase 1; PFK2, phosphofructokinase 2; ALDA, aldolase A; TPI, triose phosphate isomerase; GAPDH, glyceraldehyde 3-phosphate dehydrogenase; PGK1, phosphoglycerate kinase 1; PGM, phosphoglycerate mutase; ENO1, enolase 1; PKM2, pyruvate kinase type M2; LDH-A, lactate dehydrogenase type A: PDK1, pyruvate dehydrogenase kinase-1; TIGAR, TP53-induced glycolysis and apoptosis regulator; SCO2, synthesis of cytochrome c oxidase-2; IKK, I-kappa-B kinase; NF-KB, nuclear factor-kappa-B; GLUT, glucose transporter (154-158). 
ylation (74). p53 controls the balance between oxidative respiration and glycolysis through two important p53-inducible genes (TIGAR (46) and SCO2 (36)) as discussed above. p53 represses the transcriptional activity of GLUT1 and GLUT4 gene promoters by direct DNA binding, leading to a decrease in glucose uptake (75). Another recent report has demonstrated that the inhibitory effect of p53 on I-kappa-B kinase (IKK) dampens the positive feedback loop between glycolysis and IKK-nuclear factor-kappa-B (NF- $\mathrm{BB}$ ) signaling (76), and the loss of $\mathrm{p} 53$ will activate NF- $\mathrm{KB}$ to transcriptionally activate the expression of GLUT3 and increase the rate of aerobic glycolysis (76). p53 also induces ubiquitination and the degradation of phosphoglycerate mutase (PGM), and the loss of p53 results in an increase in the PGM protein level, resulting in enhanced glycolysis (77). Therefore, it has become clear that this triad of transcription factors, HIF-1, c-MYC and p53, are responsible for a coordinated shift in cancer cell metabolism from oxidative phosphorylation to glycolysis.

2. Lactic acid-mediated tumor progression. The accumulation of an enzyme facilitates the high conversion rate of pyruvate to lactate, and LDH-A has been observed to be critical in the development and progression of cancer. Following production, lactate is transported out of the cancer cell and across the plasma membrane by monocarboxylate transporter (MCT) family proteins. MCTs are proton-linked transporters and are involved primarily in the transport of monocarboxylic acids. MCT 1, an import transporter, is utilized in oxidative tumors to shuttle exogenous lactate as an energy source. The shuttling of lactate by MCT 1 into endothelial cells drives the CXCL8 pathway, enabling endothelial cell migration to stimulate angiogenesis. Lactate also drives the process of angiogenesis by promoting the production of VEGF (78). Furthermore, MCT1 shuttling of lactate stimulates IL-8 mRNA expression in endothelial cells,

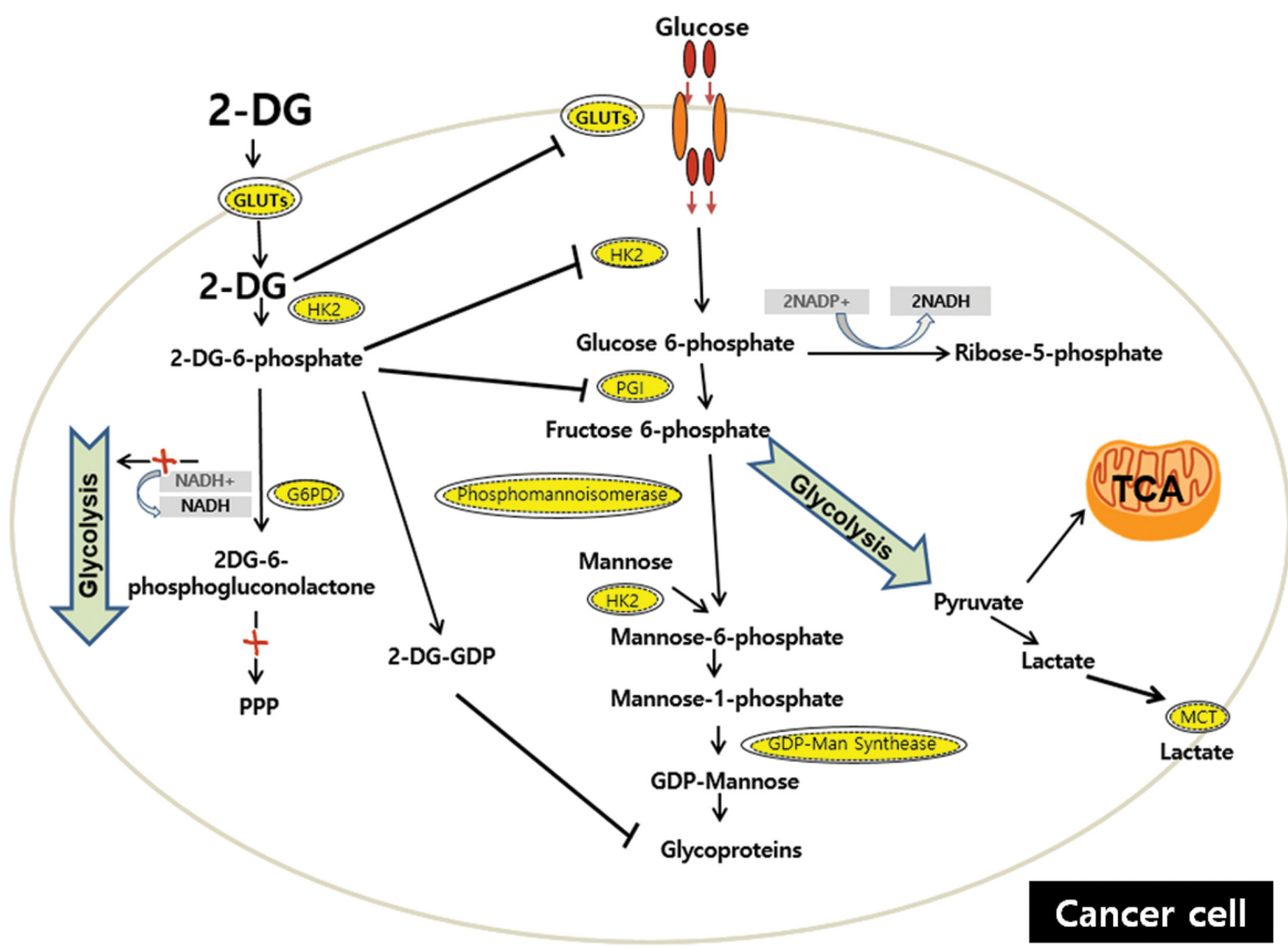

Fig. 3. The targets of 2-DG. Similar to glucose, 2-DG is taken up through GLUTs and then is phosphorylated by HK to form 2-DG-6-P, and 2-DG competitively inhibits GLUTs. 2-DG-6-P cannot be further metabolized via glycolysis but accumulates in the cell and noncompetitively inhibits HK and competitively inhibits PGI. NADPH generation is inhibited. Only one molecule of NADPH can be generated from the conversion of 2-DG-6-P to 2-DG-6-phosphogluconolactone. 2-DG structurally resembles mannose and undergoes conversion into 2-DG-GDP, which interferes with the $\mathrm{N}$-linked glycosylation of proteins. The inhibition of $\mathrm{N}$-linked glycosylation induces the accumulation of unfold/misfolded proteins in the ER, resulting in ER stress and constant cell apoptosis. Intracellular glucose can promote glycosylation because its metabolic product F-6-P can be used in the mannose glycosylation pathway. However, upstream glucose metabolism is inhibited by 2-DG, which may not allow exogenous glucose to restore the interrupted N-linked glycosylation. GLUTs, glucose transporters; HK, hexokinase; PGI, phosphoglucose isomerase; G-6-PD, glucose-6-phosphate dehydrogenase; GDP, guanosine diphosphate; MCT, monocarboxylate transporter. 
a finding that is also important for angiogenesis (79). In addition, MCT4 releases lactate from glycolytic tumors (80). Overall, as a common feature of malignant cells, increased glucose uptake and lactate production, even under normoxic conditions, is involved in cancer survival and proliferation via several mechanisms, including evading the immune system and modulating cell motility. Furthermore, the accumulation of lactate in cancer has been demonstrated to possess clinical relevance as a prognostic marker (81).

\section{Potential cancer therapy to target the Warburg effects.}

3-1. 2-Deoxy-D-glucose (2-DG): 2-DG, a synthetic glucose analog in which the C-2-hydroxyl group is replaced by hydrogen, has been extensively and thoroughly investigated in both scientific and clinical studies since the early 1950s (82). Although 2-DG has been identified as a potential anti-cancer agent by interfering with various biological process, including the depletion of cellular energy, intensification of oxidative stress, interference with N-linked glycosylation, and induction of autophagy $(83,84)$, the mechanism by which 2-DG prevents cancer is commonly thought to be via the inhibition of glycolysis. 2-DG competitively inhibits glucose uptake because it is transferred by GLUTs. After entering the cell, 2-DG is phosphorylated by HK to form 2deoxy-D-glucose-6-phosphate (2-DG-6-P), which cannot be further metabolized via glycolysis but accumulates and noncompetitively inhibits $\mathrm{HK}$ and competitively inhibits PGI $(82,85,86)$. Because 2-DG inhibits the first critical steps at the beginning of glucose metabolism, both glycolysis and OxPhos may be partially disrupted (87). These events lead to decreased ATP production, a blocked cell cycle, decreased and inhibited cell growth and even cell death $(84,88,89)$. Decreased intracellular ATP production leads to an increase in the AMP/ATP ratio, which activates and increases AMPK, resulting in elevated catabolic metabolism via the phosphorylation of downstream targets, such as mTOR (90) (see 1-14). In addition, decreased ATP sensitizes cells to extrinsic (death receptor-mediated) apoptosis $(87,91)$ via binding of tumor necrosis factor (TNF) ligand family members, including TNF-related apoptosis-inducing ligand (TRAIL), to their cognate transmembrane death receptors (92). Defects in p53

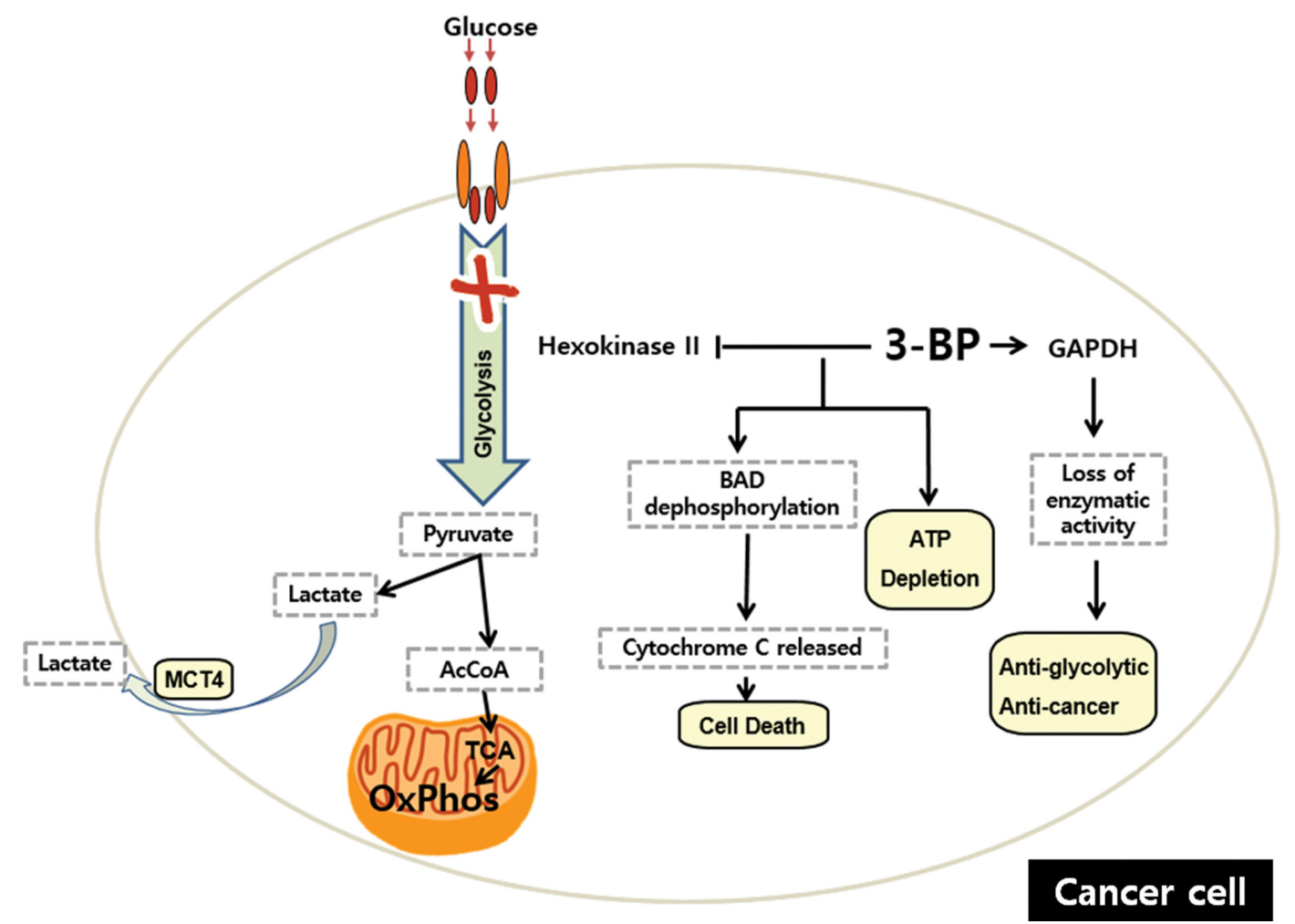

Fig. 4. DCA "switch on" mitochondria in cancer. The multi enzyme pyruvate dehydrogenase complex (PDC) is located in the mitochondrial matrix and catalyzes the rate-limiting step in the aerobic oxidation of glucose, pyruvate, alanine and lactate to acetyl CoA, a substrate of the TCA cycle. Thus, PDC is the key mediator of OxPhos. The upstream effectors of the PDC include the following: the family of pyruvate dehydrogenase kinase (PDK) isoforms that phosphorylate and inactivate PDC; the pyruvate dehydrogenase phosphatase (PDP) isoforms that dephosphorylate the PDC and restore catalytic activity. Dichloroacetic acid (DCA), a structural analog of pyruvate, stimulates PDC activation by inhibiting PDKs, thereby maintaining the PDC in its unphosphorylated form. Moreover, DCA increases PDC activity by inhibiting the turnover of the complex, although the mechanism remains unclear. 
are closely related to reduced ATP induced by 2-DG because p53 can act as an effective energy sensor of decreased ATP and restore the ATP level by promoting oxidative phosphorylation (82). HIF also reduces the efficiency of 2-DG and induces resistance by increasing glucose transporters and several glycolytic enzymes; therefore, the down-regulation of HIF sensitizes cells to the detrimental effect of 2-DG $(82,93)$. However, energy deprivation itself is not sufficient for the anti-cancer effect of 2-DG. First, ATP is necessary for both intrinsic and extrinsic-mediated apoptosis, and apoptotic cells generally have elevated levels of ATP (82). This suggests that 2-DG may paradoxically exert a cytoprotective effect. Second, 2-DG treatment, mimicking glucose deprivation, does not predispose some cells to death because they maintain OxPhos function and utilize alternative carbon sources, such as fatty acids and amino acids, to synthesize ATP under normoxic conditions (94). In addition, treatments that rescue cells from 2-DG-induced cell death, including mannose and $\mathrm{Bcl}-2$ overexpression, do not reverse the depletion of ATP (88).

3-2. Dichloroacetic acid (DCA): DCA's therapeutic potential was foreshadowed by research in the 1950 s and 1960s on the pharmacology of various ionic complexes of dichloroacetate (95). These studies led to the discovery of the DCA moiety as a molecule capable of eliciting significant effects on carbohydrate and lipid metabolism in experimental diabetes (96) and, soon thereafter, to the landmark report of its stimulatory effect on the pyruvate dehydrogenase complex (PDC) (97). These early findings led to an interest in DCA as an anti-diabetic and lipid-lowering drug (98), with potential for treating these conditions as well as myocardial and cerebrovascular ischemia $(99,100)$ and acquired (101,102) and congenital (103-105) forms of lactic acidosis, the latter, in particular, due to loss-of-function mutations in the PDC (106). The multi enzyme PDC is located in the mitochondrial matrix and catalyzes the ratelimiting step in the aerobic oxidation of glucose, pyruvate, alanine and lactate to acetyl CoA, and is thus integral to cellular energetics (107-110). The PDC is the key mediator of OxPhos. Respiration would be severely impaired if the activities of the two initiating enzymes of mitochondrial glucose and fatty acid metabolism were inhibited or if further reactions in the $\beta$-oxidation pathway were blocked. In humans, a family of PDK isoforms reversibly phosphory-

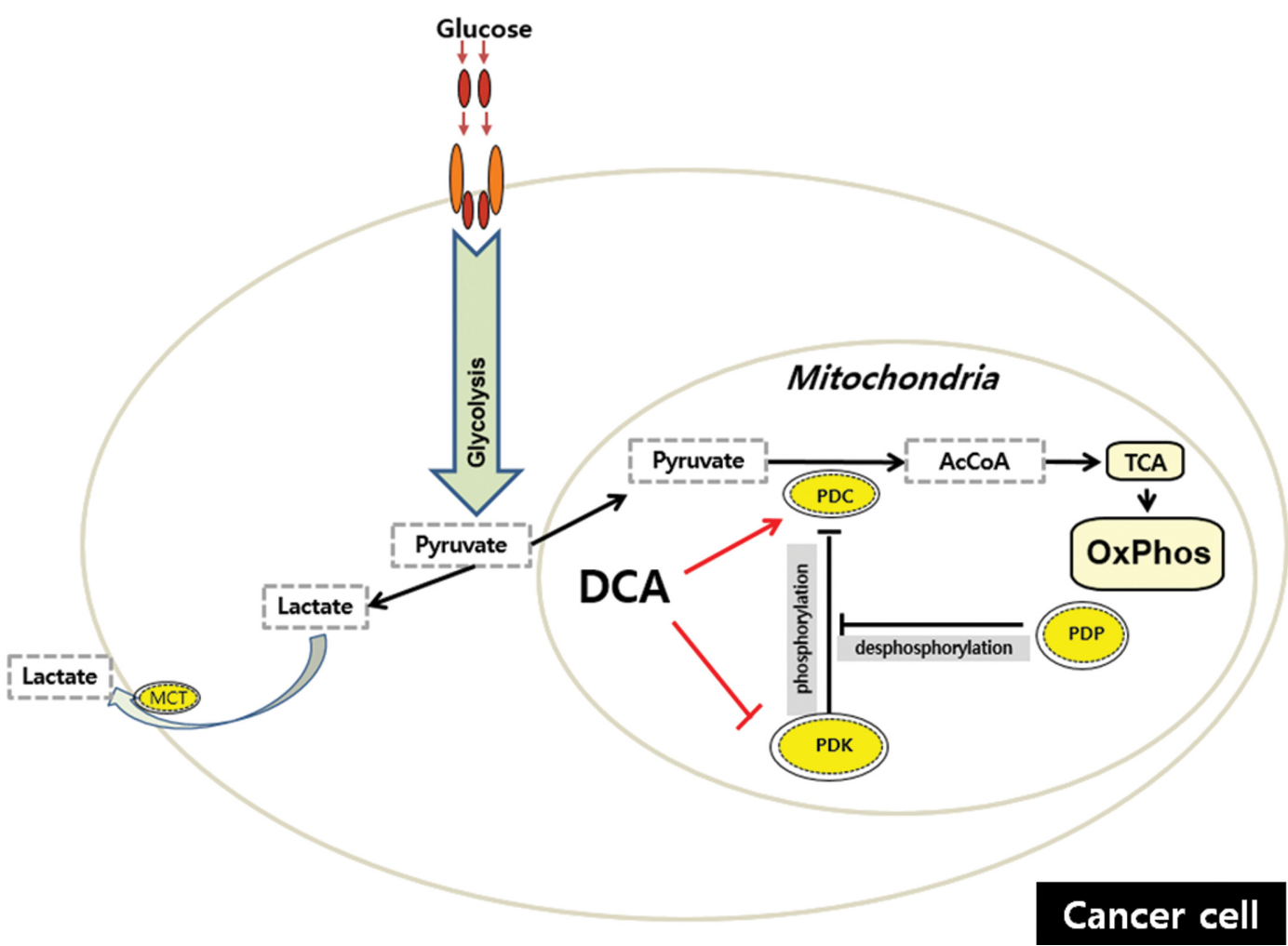

Fig. 5. Effect of 3-bromopyruvate (3-BP) on cell metabolism and survival. 3-BP dampens glycolysis by inhibiting hexokinase II and impeding the production of ATP. Furthermore, glycolysis inhibition caused by 3-BP leads to the dephosphorylation of Bcl-2-associated death promoter protein (BAD) at Ser112. Consequently, BAX, a protein required by BAD, is displaced and localized to the mitochondria, altering the mitochondrial membrane permeability and resulting in the release of cytochrome $c$ and subsequent cell death. In addition, a main target of 3-BP is the pyruvylation of glyceraldehydes-3-phosphate dehydrogenase (GAPDH), which is associated with the loss of GAPDH enzymatic activity, resulting in the anti-glycolytic and anti-cancer effects. 
lates, and inactivates, the PDC, while two pyruvate dehydrogenase phosphatase (PDP) isoforms dephosphorylate the complex and restore catalytic activity (111-113). The important thing is that the stimulatory effect of DCA on tumor cell metabolism is mediated by decreasing the expression of one or more PDK isoforms $(114,115)$. DCA, a structural analog of pyruvate, stimulates PDC activation by inhibiting PDKs, thereby maintaining the PDC in its unphosphorylated form. PDK2 is the most ubiquitously expressed kinase and is most susceptible to inhibition by DCA (110). The molecular interactions between DCA and PDKs have been studied extensively (116-119). In general, DCA appears to bind to a hydrophobic pocket in the N-terminal domain of PDK and, in the presence of ADP, disrupts the binding of the kinase to the lipoyl (E2) domain of the PDC (120). At least for the PDK1 isoform, DCA induces a conformational change in the protein that alters both nucleotide-binding and lipoylbinding pockets, inhibiting the catalytic activity of the kinase (116). PDK inhibition by DCA occurs rapidly in vivo because the stimulatory effect of the drug on PDC activity is measurable within 15 30 min of a single oral or parenteral dose and wanes within 12 24 hr after administration $(121,122)$. The increase in enzyme activity is associated temporally with significant decrements in circulating pyruvate and lactate concentrations (121). The fall in the blood lactate level is a useful surrogate marker for DCA's effect on the PDC and is dose-dependent up to at least a $50-\mathrm{mg} / \mathrm{kg}$ dose in humans (123). The other mechanism by which DCA increases PDC activity is by inhibiting the turnover of the complex. This was first demonstrated in rat liver following repeated in vivo dosing, whereby total and unphosphorylated PDC increased as a function of dose and was not prevented by pharmacological inhibitors of transcription or translation (121). Such an apparent increase in enzyme stability was also observed in the primary cultures of fibroblasts from PDC-deficient patients $(124,125)$. The molecular mechanism accounting for the stabilization of the PDC by DCA is unknown. However, it is reasonable to postulate that it may be linked to the drug-induced change in the phosphorylation state of the complex because there is considerable precedent for decreased turnover in response to changes in a protein's phosphorylation state (126-131). Regardless of the precise mechanism, stabilization of the PDC by DCA is consistent with the protracted lactate-lowering and other dynamic effects of the drug, observed with its repeated administration in humans that persist long after DCA is cleared from plasma (98).

3-3. 3-Bromopyruvate (3-BP): 3-BP has been shown to have the ability to dampen glycolysis by inhibiting hexokinase II (132). An experiment using a rat model with breast cancer highlighted the significant decrease of tumor FDG uptake $(77 \%)$ while that of normal cells was negligible, indicating the strong anti-glycolytic effect of 3-BP (133). In another experiment using a hepatocellular carcinoma rat model, it was hypothesized that, due to the increased level of lactate in many cancer cells, lactate transporters are elevated and cannot discriminate the structurally similar 3-BP from lactate, permitting the entry of 3-BP into the cells and impeding the production of ATP (134). The Bcl-2-associated death promoter protein (BAD) is a pro-apoptotic protein that regulates glycolysis and apoptosis (135). Experiments have shown glycolysis inhibition caused by 3-BP leads to concentration- and time-dependent BAD protein at Ser112 dephosphorylation. After $8 \mathrm{hr}$ of incubation, complete dephosphorylation was observed. Consequently, BAX, a protein required by $\mathrm{BAD}$ in the formation of apoptosis-preventing complexes, is displaced and localized to mitochondria, changing mitochondrial membrane permeability. Cytochrome $\mathrm{c}$ is then released and causes cell death (135). Further investigation shows that cancer cell death mediated by $3-\mathrm{BP}$ also relies on the pyruvylation of glyceraldehyde-3-phosphate dehydrogenase (GAPDH), which was identified as the main target of 3-BP. This pyruvylation is associated with the loss of GAPDH enzymatic activity, leading to the anti-glycolytic and anti-tumoral effects (136). In addition, the cytotoxicity caused by $3-\mathrm{BP}$ is not dependent on $\mathrm{p} 53$ and proved to result in massive cell death when incorporated with cisplatin and oxaliplatin (137). More importantly, a report has demonstrated that 3-BP did not cross the blood-brain barrier when the $\left[{ }^{14} \mathrm{C}\right] 3$-BP uptake was measured in the brain tissue, a finding that is crucial because the brain normally has a high glucose consumption to maintain its normal functions (138). However, 3-BP is unstable and only exhibits the inhibition of glycolysis at a high concentration (139).

3-4. Diet and cancer: Diet has frequently been connected to long life. Reducing the caloric intake can influence aging, and its mechanism is being actively researched. A possible mechanism for this event appears to involve mTOR inhibition and sirtuin activation $(140,141)$. In addition, diet is thought to be a major contributory factor in the development and progression of cancer. Epidemiological reports have emphasized that a population with low-sugar and low-fat consumption exhibits a lower incidence of cancer (142). Likewise, mice fed a diet containing low carbohydrate and high protein showed the reduction of cancer development as well as the inhibition of tumor growth (143). Links between diabetes and cancer have also been established. For example, diabetic patients treated with metformin, a drug that improves insulin sensitivity, have a reduced cancer incidence $(144,145)$. In addition, metformin and other anti-diabetic drugs inhibit transformation (146). However, confirmation is needed that these drugs indirectly regulate hormones or directly promote cell death. High-fat diets have been linked to cancer development (147). The expression of monoacylglycerol lipase (MAGL) is also correlated with tumor aggressiveness and an invasive phenotype. MAGL acted on the release of free fatty acids. siRNA-mediated reduction of MAGL led to the inhi- 
Table 2. Therapeutics targeting the Warburg effect in cancers

\begin{tabular}{|c|c|c|c|c|c|}
\hline Process & Target & Compound & Effect & Status & References \\
\hline Glucose transport & GLUT1 & WZB117, STF-31 & Inhibits CLUT1 & Preclinical & $(159,160)$ \\
\hline \multirow[t]{3}{*}{ Glycolysis } & HK & 2-DG & Inhibits HK & $\begin{array}{l}\text { Clinical trials } \\
\text { discontinued }\end{array}$ & (94) \\
\hline & PKM2 & TEPP-46 & Activates PKM2 and inhibits PPP & Preclinical & $(161,162)$ \\
\hline & LDHA & FX11 & Inhibits LDHA & Preclinical & $(163)$ \\
\hline PPP & G6PD & 6-AN & Induces oxidative stress & Preclinical & $(164)$ \\
\hline Lactate Transport & MCT1 & AZD3965 & Inhibits uptake of extracellular lactate & Phase I & $(165)$ \\
\hline Mitochondrial function & PDK1 & DCA & Inhibits PDK1 & Phase I-II & $(166,167)$ \\
\hline \multirow[t]{5}{*}{ PKB signaling pathway } & PKB & AZD5363 & Inhibits PKB activity & Phase I-II & $(168)$ \\
\hline & & GDC0068 & & Phase I & $(169)$ \\
\hline & & GSK2141795 & & Phase I completed & $(170)$ \\
\hline & & GSK2110183 & & $\begin{array}{l}\text { Phase I-II completed } \\
\text { Phase II }\end{array}$ & $(170)$ \\
\hline & & MK-2206 & & Phase I-II & (171) \\
\hline
\end{tabular}

(Adapted from (172)).

bition of invasiveness and tumor growth (148). Caloric restriction has also been known to reduce cancer incidence (149). A potential explanation is that altered levels of insulin and IGF-1 by caloric restriction function as growth factors for tumors. However, most of the studies have been performed on laboratory rodents and need to be verified in humans. Therefore, an adapted diet together with chemotherapy might be a novel way to treat cancer in the future $(150,151)$.

\section{CONCLUSION AND PERSPECTIVES}

It has been about nine decades since the proposal of Otto Warburg concerning the metabolism of cancer cells. Unlike normal cells that undergo glycolysis and oxidative phosphorylation in the presence of oxygen, proliferating and cancer cells exhibit an increased uptake of glucose and increased rate of glycolysis and, predominantly, undergo lactic acid fermentation. This metabolism finding had raised controversy over the role of mitochondria in cancer initiation, development and metastasis. While Warburg's effect demonstrated that mitochondria seem to be damaged because of nonessential OxPhos in cancer, recent studies have indicated that mitochondria are somehow required, at least in certain steps of cancer development (43). Moreover, mitochondria function as an intracellular factory or storage of danger for cytochromes and ROS. In other words, mitochondria are the master regulators of cell fate: healthy, cancer or death! $(152,153)$. Whether the Warburg phenomenon is the consequence of genetic dysregulation in cancer or the cause of cancer remains unknown. However, there are certainly strong links between the genetic factors and Warburg effects, suggesting several mechanical signaling pathways and the break down of some potential pharmacy compounds that target metabolic factors. Therapies targeting cancer cell metabolism are emerging and promising; how- ever, they are currently limited by their broad effects on different tissues. It is anticipated that further research will be aimed at developing therapeutics that may provide improved targeting for aberrant components of cancer cell metabolism.

\section{ACKNOWLEDGEMENTS}

This work was financially supported by research fund of Chungnam National University in 2014 (Jongsun Park) and by the National Research Foundation of Korea (NRF) grant funded by the Korea Government (MEST) (NRF2012M3A9B6055302, NRF-2014R1A1A3050752, NRF2015R1A2A2A01003597, NRF-2015R1D1A3A01015694).

\section{REFERENCES}

1. Warburg, O. (1915) Notizen zur Entwickelungsphysiologie des Seeigeleies. Arch.f. d. ges. Physiol., 160, 324-332.

2. Warburg, O. (1923) Versuche an überlebendem CarcinomGewebe (Methoden). Biochem. Zeitschr., 142, 317-333.

3. Warburg, O. (1924) Verbesserte Methode zur Messung der Atmung und Glykolyse. Biochem. Zeitschr., 152, 51-63.

4. Warburg, O. (1956) On the origin of cancer cells. Science, 123, 309-314.

5. Warburg, O. (1956) On respiratory impairment in cancer cells. Science, 124, 269-270.

6. Chance, B. and Castor, L.N. (1952) Some patterns of the respiratory pigments of ascites tumors of mice. Science, 116, 200-202.

7. Weinhouse, S. (1956) On respiratory impairment in cancer cells. Science, 124, 267-269.

8. Hanahan, D. and Weinberg, R.A. (2000) The hallmarks of cancer. Cell, 100, 57-70.

9. Yeung, S.J., Pan, J. and Lee, M.H. (2008) Roles of p53, MYC and HIF-1 in regulating glycolysis - the seventh hallmark of cancer. Cell. Mol. Life Sci., 65, 3981-3999.

10. Gatenby, R.A. and Gillies, R.J. (2004) Why do cancers have high aerobic glycolysis? Nat. Rev. Cancer, 4, 891-899. 
11. Brand, K.A. and Hermfisse, U. (1997) Aerobic glycolysis by proliferating cells: a protective strategy against reactive oxygen species. FASEB J., 11, 388-395.

12. Spitz, D.R., Sim, J.E., Ridnour, L.A., Galoforo, S.S. and Lee, Y.J. (2000) Glucose deprivation-induced oxidative stress in human tumor cells. A fundamental defect in metabolism? Ann. N. Y. Acad. Sci., 899, 349-362.

13. Elf, S.E. and Chen, J. (2014) Targeting glucose metabolism in patients with cancer. Cancer, 120, 774-780.

14. Hamanaka, R.B. and Chandel, N.S. (2009) Mitochondrial reactive oxygen species regulate hypoxic signaling. Curr. Opin. Cell Biol., 21, 894-899.

15. Hatefi, Y. (1985) The mitochondrial electron transport and oxidative phosphorylation system. Annu. Rev. Biochem., 54, 1015-1069.

16. Boguski, M.S., Lowe, T.M. and Tolstoshev, C.M. (1993) dbEST--database for "expressed sequence tags". Nat. Genet., 4, 332-333.

17. Altenberg, B. and Greulich, K.O. (2004) Genes of glycolysis are ubiquitously overexpressed in 24 cancer classes. Genomics, 84, 1014-1020.

18. Nachmansohn, D. (1979) German-Jewish Pioneers in Science, Springer, New York, pp. 1900-1933.

19. Koppenol, W.H., Bounds, P.L. and Dang, C.V. (2011) Otto Warburg's contributions to current concepts of cancer metabolism. Nat. Rev. Cancer, 11, 325-337.

20. Parsons, D.W., Jones, S., Zhang, X., Lin, J.C., Leary, R.J., Angenendt, P., Mankoo, P., Carter, H., Siu, I.M., Gallia, G.L., Olivi, A., McLendon, R., Rasheed, B.A., Keir, S., Nikolskaya, T., Nikolsky, Y., Busam, D.A., Tekleab, H., Diaz, L.A., Jr., Hartigan, J., Smith, D.R., Strausberg, R.L., Marie, S.K., Shinjo, S.M., Yan, H., Riggins, G.J., Bigner, D.D., Karchin, R., Papadopoulos, N., Parmigiani, G., Vogelstein, B., Velculescu, V.E. and Kinzler, K.W. (2008) An integrated genomic analysis of human glioblastoma multiforme. Science, 321, 18071812.

21. Bayley, J.P. and Devilee, P. (2010) Warburg tumours and the mechanisms of mitochondrial tumour suppressor genes. Barking up the right tree? Curr. Opin. Genet. Dev., 20, 324-329.

22. Baysal, B.E., Willett-Brozick, J.E., Lawrence, E.C., Drovdlic, C.M., Savul, S.A., McLeod, D.R., Yee, H.A., Brackmann, D.E., Slattery, W.H., 3rd, Myers, E.N., Ferrell, R.E. and Rubinstein, W.S. (2002) Prevalence of SDHB, SDHC, and SDHD germline mutations in clinic patients with head and neck paragangliomas. J. Med. Genet., 39, 178-183.

23. Baysal, B.E. (2007) A recurrent stop-codon mutation in succinate dehydrogenase subunit $\mathrm{B}$ gene in normal peripheral blood and childhood T-cell acute leukemia. PLoS ONE, 2, e436.

24. Tomlinson, I.P., Alam, N.A., Rowan, A.J., Barclay, E., Jaeger, E.E., Kelsell, D., Leigh, I., Gorman, P., Lamlum, H., Rahman, S., Roylance, R.R., Olpin, S., Bevan, S., Barker, K., Hearle, N., Houlston, R.S., Kiuru, M., Lehtonen, R., Karhu, A., Vilkki, S., Laiho, P., Eklund, C., Vierimaa, O., Aittomaki, K., Hietala, M., Sistonen, P., Paetau, A., Salovaara, R., Herva, R., Launonen, V., Aaltonen, L.A. and Multiple Leiomyoma Consortium (2002) Germline mutations in FH predispose to dominantly inherited uterine fibroids, skin leiomyomata and papillary renal cell cancer. Nat. Genet., 30, 406-410.

25. Semenza, G.L. (2012) Hypoxia-inducible factors in physiol- ogy and medicine. Cell, 148, 399-408.

26. Martin-Puig, S., Temes, E., Olmos, G., Jones, D.R., Aragones, J. and Landazuri, M.O. (2004) Role of iron (II)-2oxoglutarate-dependent dioxygenases in the generation of hypoxia-induced phosphatidic acid through HIF-1/2 and von Hippel-Lindau-independent mechanisms. J. Biol. Chem., 279, 9504-9511.

27. Chen, H. and Costa, M. (2009) Iron- and 2-oxoglutaratedependent dioxygenases: an emerging group of molecular targets for nickel toxicity and carcinogenicity. Biometals, 22, 191-196.

28. Isaacs, J.S., Jung, Y.J., Mole, D.R., Lee, S., Torres-Cabala, C., Chung, Y.L., Merino, M., Trepel, J., Zbar, B., Toro, J., Ratcliffe, P.J., Linehan, W.M. and Neckers, L. (2005) HIF overexpression correlates with biallelic loss of fumarate hydratase in renal cancer: novel role of fumarate in regulation of HIF stability. Cancer Cell, 8, 143-153.

29. King, A., Selak, M.A. and Gottlieb, E. (2006) Succinate dehydrogenase and fumarate hydratase: linking mitochondrial dysfunction and cancer. Oncogene, 25, 4675-4682.

30. Goda, N. and Kanai, M. (2012) Hypoxia-inducible factors and their roles in energy metabolism. Int. J. Hematol., 95, 457463.

31. Kim, J.W., Tchernyshyov, I., Semenza, G.L. and Dang, C.V. (2006) HIF-1-mediated expression of pyruvate dehydrogenase kinase: a metabolic switch required for cellular adaptation to hypoxia. Cell Metab., 3, 177-185.

32. Semenza, G.L., Roth, P.H., Fang, H.M. and Wang, G.L. (1994) Transcriptional regulation of genes encoding glycolytic enzymes by hypoxia-inducible factor 1 . J. Biol. Chem., 269, 2375723763.

33. Gordan, J.D., Thompson, C.B. and Simon, M.C. (2007) HIF and c-Myc: sibling rivals for control of cancer cell metabolism and proliferation. Cancer Cell, 12, 108-113.

34. Selak, M.A., Armour, S.M., MacKenzie, E.D., Boulahbel, H., Watson, D.G., Mansfield, K.D., Pan, Y., Simon, M.C., Thompson, C.B. and Gottlieb, E. (2005) Succinate links TCA cycle dysfunction to oncogenesis by inhibiting HIF-alpha prolyl hydroxylase. Cancer Cell, 7, 77-85.

35. Xu, W., Yang, H., Liu, Y., Yang, Y., Wang, P., Kim, S.H., Ito, S., Yang, C., Wang, P., Xiao, M.T., Liu, L.X., Jiang, W.Q., Liu, J., Zhang, J.Y., Wang, B., Frye, S., Zhang, Y., Xu, Y.H., Lei, Q.Y., Guan, K.L., Zhao, S.M. and Xiong, Y. (2011) Oncometabolite 2-hydroxyglutarate is a competitive inhibitor of alpha-ketoglutarate-dependent dioxygenases. Cancer Cell, 19, 17-30.

36. Matoba, S., Kang, J.G., Patino, W.D., Wragg, A., Boehm, M., Gavrilova, O., Hurley, P.J., Bunz, F. and Hwang, P.M. (2006) p53 regulates mitochondrial respiration. Science, 312, 16501653.

37. Capuano, F., Guerrieri, F. and Papa, S. (1997) Oxidative phosphorylation enzymes in normal and neoplastic cell growth. $J$. Bioenerg. Biomembr., 29, 379-384.

38. Lopez-Rios, F., Sanchez-Arago, M., Garcia-Garcia, E., Ortega, A.D., Berrendero, J.R., Pozo-Rodriguez, F., Lopez-Encuentra, A., Ballestin, C. and Cuezva, J.M. (2007) Loss of the mitochondrial bioenergetic capacity underlies the glucose avidity of carcinomas. Cancer Res., 67, 9013-9017.

39. Reitman, Z.J. and Yan, H. (2010) Isocitrate dehydrogenase 1 
and 2 mutations in cancer: alterations at a crossroads of cellular metabolism. J. Natl. Cancer Inst., 102, 932-941.

40. Gross, S., Cairns, R.A., Minden, M.D., Driggers, E.M., Bittinger, M.A., Jang, H.G., Sasaki, M., Jin, S., Schenkein, D.P., Su, S.M., Dang, L., Fantin, V.R. and Mak, T.W. (2010) Cancer-associated metabolite 2-hydroxyglutarate accumulates in acute myelogenous leukemia with isocitrate dehydrogenase 1 and 2 mutations. J. Exp. Med., 207, 339-344.

41. Zhao, S., Lin, Y., Xu, W., Jiang, W., Zha, Z., Wang, P., Yu, W., Li, Z., Gong, L., Peng, Y., Ding, J., Lei, Q., Guan, K.L. and Xiong, Y. (2009) Glioma-derived mutations in IDH1 dominantly inhibit IDH1 catalytic activity and induce HIF-1 $\alpha$. Science, 324, 261-265.

42. Cavalli, L.R., Varella-Garcia, M. and Liang, B.C. (1997) Diminished tumorigenic phenotype after depletion of mitochondrial DNA. Cell Growth Differ., 8, 1189-1198.

43. Tan, A.S., Baty, J.W., Dong, L.F., Bezawork-Geleta, A., Endaya, B., Goodwin, J., Bajzikova, M., Kovarova, J., Peterka, M., Yan, B., Pesdar, E.A., Sobol, M., Filimonenko, A., Stuart, S., Vondrusova, M., Kluckova, K., Sachaphibulkij, K., Rohlena, J., Hozak, P., Truksa, J., Eccles, D., Haupt, L.M., Griffiths, L.R., Neuzil, J. and Berridge, M.V. (2015) Mitochondrial genome acquisition restores respiratory function and tumorigenic potential of cancer cells without mitochondrial DNA. Cell Metab., 21, 81-94.

44. Okar, D.A., Manzano, A., Navarro-Sabate, A., Riera, L., Bartrons, R. and Lange, A.J. (2001) PFK-2/FBPase-2: maker and breaker of the essential biofactor fructose-2,6-bisphosphate. Trends Biochem. Sci., 26, 30-35.

45. Bensaad, K., Tsuruta, A., Selak, M.A., Vidal, M.N., Nakano, K., Bartrons, R., Gottlieb, E. and Vousden, K.H. (2006) TIGAR, a p53-inducible regulator of glycolysis and apoptosis. Cell, 126, 107-120.

46. Green, D.R. and Chipuk, J.E. (2006) p53 and metabolism: Inside the TIGAR. Cell, 126, 30-32.

47. Shim, H., Dolde, C., Lewis, B.C., Wu, C.S., Dang, G., Jungmann, R.A., Dalla-Favera, R. and Dang, C.V. (1997) c-Myc transactivation of LDH-A: implications for tumor metabolism and growth. Proc. Natl. Acad. Sci. U.S.A., 94, 6658-6663.

48. Fantin, V.R., St-Pierre, J. and Leder, P. (2006) Attenuation of LDH-A expression uncovers a link between glycolysis, mitochondrial physiology, and tumor maintenance. Cancer Cell, 9, 425-434.

49. Cardone, R.A., Casavola, V. and Reshkin, S.J. (2005) The role of disturbed $\mathrm{pH}$ dynamics and the $\mathrm{Na}+\mathrm{H}+$ exchanger in metastasis. Nat. Rev. Cancer, 5, 786-795.

50. Opavsky, R., Pastorekova, S., Zelnik, V., Gibadulinova, A., Stanbridge, E.J., Zavada, J., Kettmann, R. and Pastorek, J. (1996) Human MN/CA9 gene, a novel member of the carbonic anhydrase family: structure and exon to protein domain relationships. Genomics, 33, 480-487.

51. Ivanov, S., Liao, S.Y., Ivanova, A., Danilkovitch-Miagkova, A., Tarasova, N., Weirich, G., Merrill, M.J., Proescholdt, M.A., Oldfield, E.H., Lee, J., Zavada, J., Waheed, A., Sly, W., Lerman, M.I. and Stanbridge, E.J. (2001) Expression of hypoxia-inducible cell-surface transmembrane carbonic anhydrases in human cancer. Am. J. Pathol., 158, 905-919.

52. Robertson, N., Potter, C. and Harris, A.L. (2004) Role of carbonic anhydrase IX in human tumor cell growth, survival, and invasion. Cancer Res., 64, 6160-6165.

53. Secomb, T.W., Hsu, R., Dewhirst, M.W., Klitzman, B. and Gross, J.F. (1993) Analysis of oxygen transport to tumor tissue by microvascular networks. Int. J. Radiat. Oncol. Biol. Phys., 25, 481-489.

54. Heldin, C.H., Rubin, K., Pietras, K. and Ostman, A. (2004) High interstitial fluid pressure - an obstacle in cancer therapy. Nat. Rev. Cancer, 4, 806-813.

55. Vaupel, P., Fortmeyer, H.P., Runkel, S. and Kallinowski, F. (1987) Blood flow, oxygen consumption, and tissue oxygenation of human breast cancer xenografts in nude rats. Cancer Res., 47, 3496-3503.

56. Minchenko, O., Opentanova, I. and Caro, J. (2003) Hypoxic regulation of the 6-phosphofructo-2-kinase/fructose-2,6-bisphosphatase gene family (PFKFB-1-4) expression in vivo. FEBS Lett., 554, 264-270.

57. Minchenko, O.H., Ogura, T., Opentanova, I.L., Minchenko, D.O. and Esumi, H. (2005) Splice isoform of 6-phosphofructo-2-kinase/fructose-2,6-bisphosphatase-4: expression and hypoxic regulation. Mol. Cell. Biochem., 280, 227-234.

58. Acker, T. and Plate, K.H. (2002) A role for hypoxia and hypoxia-inducible transcription factors in tumor physiology. $J$. Mol. Med., 80, 562-575.

59. Semenza, G.L. (2000) Hypoxia, clonal selection, and the role of HIF-1 in tumor progression. Crit. Rev. Biochem. Mol. Biol., 35, 71-103.

60. Barthel, A., Okino, S.T., Liao, J., Nakatani, K., Li, J., Whitlock, J.P., Jr. and Roth, R.A. (1999) Regulation of GLUT1 gene transcription by the serine/threonine kinase Akt1. J. Biol. Chem., 274, 20281-20286.

61. Taha, C., Liu, Z., Jin, J., Al-Hasani, H., Sonenberg, N. and Klip, A. (1999) Opposite translational control of GLUT1 and GLUT4 glucose transporter mRNAs in response to insulin. Role of mammalian target of rapamycin, protein kinase $b$, and phosphatidylinositol 3-kinase in GLUT1 mRNA translation. $J$. Biol. Chem., 274, 33085-33091.

62. Majewski, N., Nogueira, V., Bhaskar, P., Coy, P.E., Skeen, J.E., Gottlob, K., Chandel, N.S., Thompson, C.B., Robey, R.B. and Hay, N. (2004) Hexokinase-mitochondria interaction mediated by Akt is required to inhibit apoptosis in the presence or absence of Bax and Bak. Mol. Cell, 16, 819-830.

63. Majewski, N., Nogueira, V., Robey, R.B. and Hay, N. (2004) Akt inhibits apoptosis downstream of BID cleavage via a glucose-dependent mechanism involving mitochondrial hexokinases. Mol. Cell. Biol., 24, 730-740.

64. Bauer, D.E., Hatzivassiliou, G., Zhao, F., Andreadis, C. and Thompson, C.B. (2005) ATP citrate lyase is an important component of cell growth and transformation. Oncogene, 24, 6314-6322.

65. Deberardinis, R.J., Lum, J.J. and Thompson, C.B. (2006) Phosphatidylinositol 3-kinase-dependent modulation of carnitine palmitoyltransferase $1 \mathrm{~A}$ expression regulates lipid metabolism during hematopoietic cell growth. J. Biol. Chem., 281, 37372-37380.

66. Albanell, J., Dalmases, A., Rovira, A. and Rojo, F. (2007) mTOR signalling in human cancer. Clin. Transl. Oncol., 9, 484-493.

67. Chiang, G.G. and Abraham, R.T. (2007) Targeting the mTOR signaling network in cancer. Trends Mol. Med., 13, 433-442.

68. Martin, D.E. and Hall, M.N. (2005) The expanding TOR sig- 
naling network. Curr. Opin. Cell Biol., 17, 158-166.

69. Hudson, C.C., Liu, M., Chiang, G.G., Otterness, D.M., Loomis, D.C., Kaper, F., Giaccia, A.J. and Abraham, R.T. (2002) Regulation of hypoxia-inducible factor 1alpha expression and function by the mammalian target of rapamycin. Mol. Cell. Biol., 22, 7004-7014.

70. Mathupala, S.P., Rempel, A. and Pedersen, P.L. (1997) Aberrant glycolytic metabolism of cancer cells: a remarkable coordination of genetic, transcriptional, post-translational, and mutational events that lead to a critical role for type II hexokinase. J. Bioenerg. Biomembr., 29, 339-343.

71. Dang, C.V., Lewis, B.C., Dolde, C., Dang, G. and Shim, H. (1997) Oncogenes in tumor metabolism, tumorigenesis, and apoptosis. J. Bioenerg. Biomembr., 29, 345-354.

72. Dang, C.V. and Semenza, G.L. (1999) Oncogenic alterations of metabolism. Trends Biochem. Sci., 24, 68-72.

73. Lu, H., Forbes, R.A. and Verma, A. (2002) Hypoxia-inducible factor 1 activation by aerobic glycolysis implicates the Warburg effect in carcinogenesis. J. Biol. Chem., 277, 2311123115.

74. Kim, J.W., Gao, P., Liu, Y.C., Semenza, G.L. and Dang, C.V. (2007) Hypoxia-inducible factor 1 and dysregulated c-Myc cooperatively induce vascular endothelial growth factor and metabolic switches hexokinase 2 and pyruvate dehydrogenase kinase 1. Mol. Cell. Biol., 27, 7381-7393.

75. Schwartzenberg-Bar-Yoseph, F., Armoni, M. and Karnieli, E. (2004) The tumor suppressor p53 down-regulates glucose transporters GLUT1 and GLUT4 gene expression. Cancer Res., 64, 2627-2633.

76. Kawauchi, K., Araki, K., Tobiume, K. and Tanaka, N. (2008) p53 regulates glucose metabolism through an IKK-NF- $\mathrm{KB}$ pathway and inhibits cell transformation. Nat. Cell Biol., 10, 611-618.

77. Kondoh, H., Lleonart, M.E., Gil, J., Wang, J., Degan, P., Peters, G., Martinez, D., Carnero, A. and Beach, D. (2005) Glycolytic enzymes can modulate cellular life span. Cancer Res., 65, 177-185.

78. Beckert, S., Farrahi, F., Aslam, R.S., Scheuenstuhl, H., Konigsrainer, A., Hussain, M.Z. and Hunt, T.K. (2006) Lactate stimulates endothelial cell migration. Wound Repair Regen., 14, 321-324.

79. Vegran, F., Boidot, R., Michiels, C., Sonveaux, P. and Feron, O. (2011) Lactate influx through the endothelial cell monocarboxylate transporter MCT1 supports an NF- $\mathrm{BB} / \mathrm{IL}-8$ pathway that drives tumor angiogenesis. Cancer Res., 71, 2550-2560.

80. Draoui, N. and Feron, O. (2011) Lactate shuttles at a glance: from physiological paradigms to anti-cancer treatments. Dis. Model. Mech., 4, 727-732.

81. Hirschhaeuser, F., Sattler, U.G. and Mueller-Klieser, W. (2011) Lactate: a metabolic key player in cancer. Cancer Res., 71, 6921-6925.

82. Kurtoglu, M., Maher, J.C. and Lampidis, T.J. (2007) Differential toxic mechanisms of 2-deoxy-D-glucose versus 2-fluorodeoxy-D-glucose in hypoxic and normoxic tumor cells. Antioxid. Redox Signal., 9, 1383-1390.

83. Bandugula, V.R. and N, R.P. (2013) 2-Deoxy-D-glucose and ferulic acid modulates radiation response signaling in nonsmall cell lung cancer cells. Tumour Biol., 34, 251-259.

84. Giammarioli, A.M., Gambardella, L., Barbati, C., Pietraforte,
D., Tinari, A., Alberton, M., Gnessi, L., Griffin, R.J., Minetti, M. and Malorni, W. (2012) Differential effects of the glycolysis inhibitor 2-deoxy-D-glucose on the activity of pro-apoptotic agents in metastatic melanoma cells, and induction of a cytoprotective autophagic response. Int. J. Cancer, 131, E337E347.

85. Ralser, M., Wamelink, M.M., Struys, E.A., Joppich, C., Krobitsch, S., Jakobs, C. and Lehrach, H. (2008) A catabolic block does not sufficiently explain how 2-deoxy-D-glucose inhibits cell growth. Proc. Natl. Acad. Sci. U.S.A., 105, 17807-17811.

86. Urakami, K., Zangiacomi, V., Yamaguchi, K. and Kusuhara, M. (2013) Impact of 2-deoxy-D-glucose on the target metabolome profile of a human endometrial cancer cell line. Biomed. Res., 34, 221-229.

87. Robinson, G.L., Dinsdale, D., Macfarlane, M. and Cain, K. (2012) Switching from aerobic glycolysis to oxidative phosphorylation modulates the sensitivity of mantle cell lymphoma cells to TRAIL. Oncogene, 31, 4996-5006.

88. Zagorodna, O., Martin, S.M., Rutkowski, D.T., Kuwana, T., Spitz, D.R. and Knudson, C.M. (2012) 2-Deoxyglucose-induced toxicity is regulated by Bcl-2 family members and is enhanced by antagonizing Bcl-2 in lymphoma cell lines. Oncogene, 31, 2738-2749.

89. Golding, J.P., Wardhaugh, T., Patrick, L., Turner, M., Phillips, J.B., Bruce, J.I. and Kimani, S.G. (2013) Targeting tumour energy metabolism potentiates the cytotoxicity of 5-aminolevulinic acid photodynamic therapy. Br. J. Cancer, 109, 976-982.

90. Kim, S.M., Yun, M.R., Hong, Y.K., Solca, F., Kim, J.H., Kim, H.J. and Cho, B.C. (2013) Glycolysis inhibition sensitizes non-small cell lung cancer with T790M mutation to irreversible EGFR inhibitors via translational suppression of Mcl-1 by AMPK activation. Mol. Cancer Ther, 12, 2145-2156.

91. Wood, T.E., Dalili, S., Simpson, C.D., Hurren, R., Mao, X., Saiz, F.S., Gronda, M., Eberhard, Y., Minden, M.D., Bilan, P.J., Klip, A., Batey, R.A. and Schimmer, A.D. (2008) A novel inhibitor of glucose uptake sensitizes cells to FAS-induced cell death. Mol. Cancer Ther., 7, 3546-3555.

92. Yamaguchi, R., Janssen, E., Perkins, G., Ellisman, M., Kitada, S. and Reed, J.C. (2011) Efficient elimination of cancer cells by deoxyglucose-ABT-263/737 combination therapy. PLoS ONE, 6, e24102.

93. Maher, J.C., Wangpaichitr, M., Savaraj, N., Kurtoglu, M. and Lampidis, T.J. (2007) Hypoxia-inducible factor-1 confers resistance to the glycolytic inhibitor 2-deoxy-D-glucose. Mol. Cancer Ther, 6, 732-741.

94. Raez, L.E., Papadopoulos, K., Ricart, A.D., Chiorean, E.G., Dipaola, R.S., Stein, M.N., Rocha Lima, C.M., Schlesselman, J.J., Tolba, K., Langmuir, V.K., Kroll, S., Jung, D.T., Kurtoglu, M., Rosenblatt, J. and Lampidis, T.J. (2013) A phase I dose-escalation trial of 2-deoxy-D-glucose alone or combined with docetaxel in patients with advanced solid tumors. Cancer Chemother. Pharmacol., 71, 523-530.

95. Stacpoole, P.W. (1969) Review of the pharmacologic and therapeutic effects of diisopropylammonium dichloroacetate (DIPA). J. Clin. Pharmacol. J. New Drugs, 9, 282-291.

96. Stacpoole, P.W. and Felts, J.M. (1970) Diisopropylammonium dichloroacetate (DIPA) and sodium dichloracetate (DCA): effect on glucose and fat metabolism in normal and diabetic tissue. Metabolism, 19, 71-78. 
97. Whitehouse, S. and Randle, P.J. (1973) Activation of pyruvate dehydrogenase in perfused rat heart by dichloroacetate (Short Communication). Biochem. J., 134, 651-653.

98. Stacpoole, P.W., Moore, G.W. and Kornhauser, D.M. (1978) Metabolic effects of dichloroacetate in patients with diabetes mellitus and hyperlipoproteinemia. N. Engl. J. Med., 298, 526-530.

99. Stacpoole, P.W. (1989) The pharmacology of dichloroacetate. Metabolism, 38, 1124-1144.

100. Bersin, R.M. and Stacpoole, P.W. (1997) Dichloroacetate as metabolic therapy for myocardial ischemia and failure. $\mathrm{Am}$. Heart J., 134, 841-855.

101. Stacpoole, P.W., Harman, E.M., Curry, S.H., Baumgartner, T.G. and Misbin, R.I. (1983) Treatment of lactic acidosis with dichloroacetate. N. Engl. J. Med., 309, 390-396.

102. Stacpoole, P.W., Wright, E.C., Baumgartner, T.G., Bersin, R.M., Buchalter, S., Curry, S.H., Duncan, C.A., Harman, E.M., Henderson, G.N., Jenkinson, S., et al. (1992) A controlled clinical trial of dichloroacetate for treatment of lactic acidosis in adults. The Dichloroacetate-Lactic Acidosis Study Group. N. Engl. J. Med., 327, 1564-1569.

103. Stacpoole, P.W., Kerr, D.S., Barnes, C., Bunch, S.T., Carney, P.R., Fennell, E.M., Felitsyn, N.M., Gilmore, R.L., Greer, M., Henderson, G.N., Hutson, A.D., Neiberger, R.E., O’Brien, R.G., Perkins, L.A., Quisling, R.G., Shroads, A.L., Shuster, J.J., Silverstein, J.H., Theriaque, D.W. and Valenstein, E. (2006) Controlled clinical trial of dichloroacetate for treatment of congenital lactic acidosis in children. Pediatrics, 117, 1519-1531.

104. Stacpoole, P.W., Gilbert, L.R., Neiberger, R.E., Carney, P.R., Valenstein, E., Theriaque, D.W. and Shuster, J.J. (2008) Evaluation of long-term treatment of children with congenital lactic acidosis with dichloroacetate. Pediatrics, 121, e1223-e1228.

105. Berendzen, K., Theriaque, D.W., Shuster, J. and Stacpoole, P.W. (2006) Therapeutic potential of dichloroacetate for pyruvate dehydrogenase complex deficiency. Mitochondrion, 6, 126-135.

106. Kaufmann, P., Engelstad, K., Wei, Y., Jhung, S., Sano, M.C., Shungu, D.C., Millar, W.S., Hong, X., Gooch, C.L., Mao, X., Pascual, J.M., Hirano, M., Stacpoole, P.W., DiMauro, S. and De Vivo, D.C. (2006) Dichloroacetate causes toxic neuropathy in MELAS: a randomized, controlled clinical trial. Neurology, 66, 324-330.

107. Zhou, Z.H., McCarthy, D.B., O'Connor, C.M., Reed, L.J. and Stoops, J.K. (2001) The remarkable structural and functional organization of the eukaryotic pyruvate dehydrogenase complexes. Proc. Natl. Acad. Sci. U.S.A., 98, 14802-14807.

108. Smolle, M., Prior, A.E., Brown, A.E., Cooper, A., Byron, O. and Lindsay, J.G. (2006) A new level of architectural complexity in the human pyruvate dehydrogenase complex. $J$. Biol. Chem., 281, 19772-19780.

109. Brautigam, C.A., Wynn, R.M., Chuang, J.L., Machius, M., Tomchick, D.R. and Chuang, D.T. (2006) Structural insight into interactions between dihydrolipoamide dehydrogenase (E3) and E3 binding protein of human pyruvate dehydrogenase complex. Structure, 14, 611-621.1

110. Bowker-Kinley, M.M., Davis, W.I., Wu, P., Harris, R.A. and Popov, K.M. (1998) Evidence for existence of tissue-spe- cific regulation of the mammalian pyruvate dehydrogenase complex. Biochem. J., 329, 191-196.

111. Huang, B., Wu, P., Popov, K.M. and Harris, R.A. (2003) Starvation and diabetes reduce the amount of pyruvate dehydrogenase phosphatase in rat heart and kidney. Diabetes, 52, 1371-1376.

112. Motojima, K. and Seto, K. (2003) Fibrates and statins rapidly and synergistically induce pyruvate dehydrogenase kinase 4 mRNA in the liver and muscles of mice. Biol. Pharm. Bull., 26, 954-958.

113. Hsieh, M.C., Das, D., Sambandam, N., Zhang, M.Q. and Nahle, Z. (2008) Regulation of the PDK4 isozyme by the Rb-E2F1 complex. J. Biol. Chem., 283, 27410-27417.

114. Velpula, K.K., Bhasin, A., Asuthkar, S. and Tsung, A.J. (2013) Combined targeting of PDK1 and EGFR triggers regression of glioblastoma by reversing the Warburg effect. Cancer Res., 73, 7277-7289.

115. Heshe, D., Hoogestraat, S., Brauckmann, C., Karst, U., Boos, J. and Lanvers-Kaminsky, C. (2011) Dichloroacetate metabolically targeted therapy defeats cytotoxicity of standard anticancer drugs. Cancer Chemother. Pharmacol., 67, 647655.

116. Roche, T.E., Baker, J.C., Yan, X., Hiromasa, Y., Gong, X., Peng, T., Dong, J., Turkan, A. and Kasten, S.A. (2001) Distinct regulatory properties of pyruvate dehydrogenase kinase and phosphatase isoforms. Prog. Nucleic Acid Res. Mol. Biol., 70, 33-75.

117. Bao, H., Kasten, S.A., Yan, X. and Roche, T.E. (2004) Pyruvate dehydrogenase kinase isoform 2 activity limited and further inhibited by slowing down the rate of dissociation of ADP. Biochemistry, 43, 13432-13441.

118. Kato, M., Li, J., Chuang, J.L. and Chuang, D.T. (2007) Distinct structural mechanisms for inhibition of pyruvate dehydrogenase kinase isoforms by AZD7545, dichloroacetate, and radicicol. Structure, 15, 992-1004.

119. Klyuyeva, A., Tuganova, A. and Popov, K.M. (2007) Amino acid residues responsible for the recognition of dichloroacetate by pyruvate dehydrogenase kinase 2. FEBS Lett., 581, 2988-2992.

120. Li, J., Kato, M. and Chuang, D.T. (2009) Pivotal role of the C-terminal DW-motif in mediating inhibition of pyruvate dehydrogenase kinase 2 by dichloroacetate. J. Biol. Chem., 284, 34458-34467.

121. Evans, O.B. and Stacpoole, P.W. (1982) Prolonged hypolactatemia and increased total pyruvate dehydrogenase activity by dichloroacetate. Biochem. Pharmacol., 31, 1295-1300.

122. Curry, S.H., Chu, P.I., Baumgartner, T.G. and Stacpoole, P.W. (1985) Plasma concentrations and metabolic effects of intravenous sodium dichloroacetate. Clin. Pharmacol. Ther, 37, 89-93.

123. Stacpoole, P.W., Nagaraja, N.V. and Hutson, A.D. (2003) Efficacy of dichloroacetate as a lactate-lowering drug. $J$. Clin. Pharmacol., 43, 683-691.

124. Morten, K.J., Caky, M. and Matthews, P.M. (1998) Stabilization of the pyruvate dehydrogenase E1alpha subunit by dichloroacetate. Neurology, 51, 1331-1335.

125. Han, Z., Berendzen, K., Zhong, L., Surolia, I., Chouthai, N., Zhao, W., Maina, N., Srivastava, A. and Stacpoole, P.W. (2008) A combined therapeutic approach for pyruvate dehy- 
drogenase deficiency using self-complementary adeno-associated virus serotype-specific vectors and dichloroacetate. Mol. Genet. Metab., 93, 381-387.

126. Ishida, N., Kitagawa, M., Hatakeyama, S. and Nakayama, K. (2000) Phosphorylation at serine 10, a major phosphorylation site of p27(Kip1), increases its protein stability. J. Biol. Chem., 275, 25146-25154.

127. Lu, K.P., Liou, Y.C. and Zhou, X.Z. (2002) Pinning down proline-directed phosphorylation signaling. Trends Cell Biol., 12, 164-172.

128. Virshup, D.M., Eide, E.J., Forger, D.B., Gallego, M. and Harnish, E.V. (2007) Reversible protein phosphorylation regulates circadian rhythms. Cold Spring Harb. Symp. Quant. Biol., 72, 413-420.

129. Moretto-Zita, M., Jin, H., Shen, Z., Zhao, T., Briggs, S.P. and Xu, Y. (2010) Phosphorylation stabilizes Nanog by promoting its interaction with Pin1. Proc. Natl. Acad. Sci. U.S.A., 107, 13312-13317.

130. Ozlu, N., Akten, B., Timm, W., Haseley, N., Steen, H. and Steen, J.A. (2010) Phosphoproteomics. Wiley Interdiscip. Rev. Syst. Biol. Med., 2, 255-276.

131. Thomas, L.W., Lam, C. and Edwards, S.W. (2010) Mcl-1; the molecular regulation of protein function. FEBS Lett., 584, 2981-2989.

132. Geschwind, J.F., Georgiades, C.S., Ko, Y.H. and Pedersen, P.L. (2004) Recently elucidated energy catabolism pathways provide opportunities for novel treatments in hepatocellular carcinoma. Expert Rev. Anticancer Ther, 4, 449-457.

133. Buijs, M., Vossen, J.A., Geschwind, J.F., Ishimori, T., Engles, J.M., Acha-Ngwodo, O., Wahl, R.L. and Vali, M. (2009) Specificity of the anti-glycolytic activity of 3-bromopyruvate confirmed by FDG uptake in a rat model of breast cancer. Invest. New Drugs, 27, 120-123.

134. Ko, Y.H., Smith, B.L., Wang, Y., Pomper, M.G., Rini, D.A., Torbenson, M.S., Hullihen, J. and Pedersen, P.L. (2004) Advanced cancers: eradication in all cases using 3-bromopyruvate therapy to deplete ATP. Biochem. Biophys. Res. Commun., 324, 269-275.

135. Danial, N.N., Gramm, C.F., Scorrano, L., Zhang, C.Y., Krauss, S., Ranger, A.M., Datta, S.R., Greenberg, M.E., Licklider, L.J., Lowell, B.B., Gygi, S.P. and Korsmeyer, S.J. (2003) BAD and glucokinase reside in a mitochondrial complex that integrates glycolysis and apoptosis. Nature, 424, 952-956.

136. Ganapathy-Kanniappan, S., Geschwind, J.F., Kunjithapatham, R., Buijs, M., Vossen, J.A., Tchernyshyov, I., Cole, R.N., Syed, L.H., Rao, P.P., Ota, S. and Vali, M. (2009) Glyceraldehyde-3-phosphate dehydrogenase (GAPDH) is pyruvylated during 3-bromopyruvate mediated cancer cell death. Anticancer Res., 29, 4909-4918.

137. Ihrlund, L.S., Hernlund, E., Khan, O. and Shoshan, M.C. (2008) 3-Bromopyruvate as inhibitor of tumour cell energy metabolism and chemopotentiator of platinum drugs. Mol. Oncol., 2, 94-101.

138. Vali, M., Vossen, J.A., Buijs, M., Engles, J.M., Liapi, E., Ventura, V.P., Khwaja, A., Acha-Ngwodo, O., Ganapathy-Kanniappan, S., Syed, L., Wahl, R.L. and Geschwind, J.F. (2008) Targeting of VX2 rabbit liver tumor by selective delivery of 3-bromopyruvate: a biodistribution and survival study. $J$.
Pharmacol. Exp. Ther, 327, 32-37.

139. Xu, R.H., Pelicano, H., Zhou, Y., Carew, J.S., Feng, L., Bhalla, K.N., Keating, M.J. and Huang, P. (2005) Inhibition of glycolysis in cancer cells: a novel strategy to overcome drug resistance associated with mitochondrial respiratory defect and hypoxia. Cancer Res., 65, 613-621.

140. Blagosklonny, M.V. (2010) Linking calorie restriction to longevity through sirtuins and autophagy: any role for TOR. Cell Death Dis., 1, e12.

141. Morselli, E., Maiuri, M.C., Markaki, M., Megalou, E., Pasparaki, A., Palikaras, K., Criollo, A., Galluzzi, L., Malik, S.A., Vitale, I., Michaud, M., Madeo, F., Tavernarakis, N. and Kroemer, G. (2010) Caloric restriction and resveratrol promote longevity through the Sirtuin-1-dependent induction of autophagy. Cell Death Dis., 1, e10.

142. Willcox, D.C., Willcox, B.J., Todoriki, H. and Suzuki, M. (2009) The Okinawan diet: health implications of a low-calorie, nutrient-dense, antioxidant-rich dietary pattern low in glycemic load. J. Am. Coll. Nutr., 28 Suppl, 500S-516S.

143. Ho, V.W., Leung, K., Hsu, A., Luk, B., Lai, J., Shen, S.Y., Minchinton, A.I., Waterhouse, D., Bally, M.B., Lin, W., Nelson, B.H., Sly, L.M. and Krystal, G. (2011) A low carbohydrate, high protein diet slows tumor growth and prevents cancer initiation. Cancer Res., 71, 4484-4493.

144. Bowker, S.L., Majumdar, S.R., Veugelers, P. and Johnson, J.A. (2006) Increased cancer-related mortality for patients with type 2 diabetes who use sulfonylureas or insulin. Diabetes Care, 29, 254-258.

145. Evans, J.M., Donnelly, L.A., Emslie-Smith, A.M., Alessi, D.R. and Morris, A.D. (2005) Metformin and reduced risk of cancer in diabetic patients. BMJ, 330, 1304-1305.

146. Nicklin, P., Bergman, P., Zhang, B., Triantafellow, E., Wang, H., Nyfeler, B., Yang, H., Hild, M., Kung, C., Wilson, C., Myer, V.E., MacKeigan, J.P., Porter, J.A., Wang, Y.K., Cantley, L.C., Finan, P.M. and Murphy, L.O. (2009) Bidirectional transport of amino acids regulates mTOR and autophagy. Cell, 136, 521-534.

147. Venkateswaran, V. and Klotz, L.H. (2010) Diet and prostate cancer: mechanisms of action and implications for chemoprevention. Nat. Rev. Urol., 7, 442-453.

148. Nomura, D.K., Long, J.Z., Niessen, S., Hoover, H.S., Ng, S.W. and Cravatt, B.F. (2010) Monoacylglycerol lipase regulates a fatty acid network that promotes cancer pathogenesis. Cell, 140, 49-61.

149. Hursting, S.D., Lavigne, J.A., Berrigan, D., Perkins, S.N. and Barrett, J.C. (2003) Calorie restriction, aging, and cancer prevention: mechanisms of action and applicability to humans. Annu. Rev. Med., 54, 131-152.

150. El Mjiyad, N., Caro-Maldonado, A., Ramirez-Peinado, S. and Munoz-Pinedo, C. (2011) Sugar-free approaches to cancer cell killing. Oncogene, 30, 253-264.

151. Lee, C. and Longo, V.D. (2011) Fasting vs dietary restriction in cellular protection and cancer treatment: from model organisms to patients. Oncogene, 30, 3305-3316.

152. Wallace, D.C. (2012) Mitochondria and cancer. Nat. Rev. Cancer, 12, 685-698.

153. Galluzzi, L., Kepp, O. and Kroemer, G. (2012) Mitochondria: master regulators of danger signalling. Nat. Rev. Mol. Cell Biol., 13, 780-788. 
154. Cheon, J.M., Kim, D.I. and Kim, K.S. (2015) Insulin sensitivity improvement of fermented Korean Red Ginseng (Panax ginseng) mediated by insulin resistance hallmarks in old-aged ob/ob mice. J. Ginseng Res., 39, 331-337.

155. Kim, A.Y., Kwak, J.H., Je, N.K., Lee, Y.H. and Jung, Y.S. (2015) Epithelial-mesenchymal transition is associated with acquired resistance to 5-fluorocuracil in HT-29 colon cancer cells. Toxicol. Res., 31, 151-156.

156. Kim, I.S., Yang, S.Y., Han, J.H., Jung, S.H., Park, H.S. and Myung, C.S. (2015) Differential gene expression in GPR40overexpressing pancreatic beta-cells treated with linoleic acid. Korean J. Physiol. Pharmacol., 19, 141-149.

157. Li, Y., Park, J., Piao, L., Kong, G., Kim, Y., Park, K.A., Zhang, T., Hong, J., Hur, G.M., Seok, J.H., Choi, S.W., Yoo, B.C., Hemmings, B.A., Brazil, D.P., Kim, S.H. and Park, J. (2013) PKB-mediated PHF20 phosphorylation on Ser291 is required for p53 function in DNA damage. Cell. Signal., 25, 74-84

158. Na, C.H., Hong, J.H., Kim, W.S., Shanta, S.R., Bang, J.Y., Park, D., Kim, H.K. and Kim, K.P. (2015) Identification of protein markers specific for papillary renal cell carcinoma using imaging mass spectrometry. Mol. Cells, 38, 624-629.

159. Liu, Y., Cao, Y., Zhang, W., Bergmeier, S., Qian, Y., Akbar, H., Colvin, R., Ding, J., Tong, L., Wu, S., Hines, J. and Chen, X. (2012) A small-molecule inhibitor of glucose transporter 1 downregulates glycolysis, induces cell-cycle arrest, and inhibits cancer cell growth in vitro and in vivo. Mol. Cancer Ther., 11, 1672-1682.

160. Chan, D.A., Sutphin, P.D., Nguyen, P., Turcotte, S., Lai, E.W., Banh, A., Reynolds, G.E., Chi, J.T., Wu, J., SolowCordero, D.E., Bonnet, M., Flanagan, J.U., Bouley, D.M., Graves, E.E., Denny, W.A., Hay, M.P. and Giaccia, A.J. (2011) Targeting GLUT1 and the Warburg effect in renal cell carcinoma by chemical synthetic lethality. Sci. Transl. Med., 3, 94ra70.

161. Anastasiou, D., Yu, Y., Israelsen, W.J., Jiang, J.K., Boxer, M.B., Hong, B.S., Tempel, W., Dimov, S., Shen, M., Jha, A., Yang, H., Mattaini, K.R., Metallo, C.M., Fiske, B.P., Courtney, K.D., Malstrom, S., Khan, T.M., Kung, C., Skoumbourdis, A.P., Veith, H., Southall, N., Walsh, M.J., Brimacombe, K.R., Leister, W., Lunt, S.Y., Johnson, Z.R., Yen, K.E., Kunii, K., Davidson, S.M., Christofk, H.R., Austin, C.P., Inglese, J., Harris, M.H., Asara, J.M., Stephanopoulos, G., Salituro, F.G., Jin, S., Dang, L., Auld, D.S., Park, H.W., Cantley, L.C., Thomas, C.J. and Vander Heiden, M.G. (2012) Pyruvate kinase M2 activators promote tetramer formation and suppress tumorigenesis. Nat. Chem. Biol., 8, 839-847.

162. Kung, C., Hixon, J., Choe, S., Marks, K., Gross, S., Murphy, E., DeLaBarre, B., Cianchetta, G., Sethumadhavan, S., Wang, X., Yan, S., Gao, Y., Fang, C., Wei, W., Jiang, F., Wang, S., Qian, K., Saunders, J., Driggers, E., Woo, H.K., Kunii, K., Murray, S., Yang, H., Yen, K., Liu, W., Cantley, L.C., Vander Heiden, M.G., Su, S.M., Jin, S., Salituro, F.G. and Dang, L. (2012) Small molecule activation of PKM2 in cancer cells induces serine auxotrophy. Chem. Biol., 19, 1187-1198.

163. Le, A., Cooper, C.R., Gouw, A.M., Dinavahi, R., Maitra, A.,
Deck, L.M., Royer, R.E., Vander Jagt, D.L., Semenza, G.L. and Dang, C.V. (2010) Inhibition of lactate dehydrogenase A induces oxidative stress and inhibits tumor progression. Proc. Natl. Acad. Sci. U.S.A., 107, 2037-2042.

164. Bhardwaj, R., Sharma, P.K., Jadon, S.P. and Varshney, R. (2012) A combination of 2-deoxy-D-glucose and 6-aminonicotinamide induces cell cycle arrest and apoptosis selectively in irradiated human malignant cells. Tumour Biol., 33, 1021-1030.

165. Sonveaux, P., Vegran, F., Schroeder, T., Wergin, M.C., Verrax, J., Rabbani, Z.N., De Saedeleer, C.J., Kennedy, K.M., Diepart, C., Jordan, B.F., Kelley, M.J., Gallez, B., Wahl, M.L., Feron, O. and Dewhirst, M.W. (2008) Targeting lactate-fueled respiration selectively kills hypoxic tumor cells in mice. $J$. Clin. Invest., 118, 3930-3942.

166. Michelakis, E.D., Webster, L. and Mackey, J.R. (2008) Dichloroacetate (DCA) as a potential metabolic-targeting therapy for cancer. Br. J. Cancer, 99, 989-994.

167. Strum, S.B., Adalsteinsson, O., Black, R.R., Segal, D., Peress, N.L. and Waldenfels, J. (2013) Case report: Sodium dichloroacetate (DCA) inhibition of the "Warburg Effect" in a human cancer patient: complete response in non-Hodgkin's lymphoma after disease progression with rituximabCHOP. J. Bioenerg. Biomembr., 45, 307-315.

168. Addie, M., Ballard, P., Buttar, D., Crafter, C., Currie, G., Davies, B.R., Debreczeni, J., Dry, H., Dudley, P., Greenwood, R., Johnson, P.D., Kettle, J.G., Lane, C., Lamont, G., Leach, A., Luke, R.W., Morris, J., Ogilvie, D., Page, K., Pass, M., Pearson, S. and Ruston, L. (2013) Discovery of 4-amino-N[(1S)-1-(4-chlorophenyl)-3-hydroxypropyl]-1-(7H-pyrrolo[2,3d]pyrimidin-4-yl)piperidine-4-carboxamide (AZD5363), an orally bioavailable, potent inhibitor of Akt kinases. J. Med. Chem., 56, 2059-2073.

169. Lin, J., Sampath, D., Nannini, M.A., Lee, B.B., Degtyarev, M., Oeh, J., Savage, H., Guan, Z., Hong, R., Kassees, R., Lee, L.B., Risom, T., Gross, S., Liederer, B.M., Koeppen, H., Skelton, N.J., Wallin, J.J., Belvin, M., Punnoose, E., Friedman, L.S. and Lin, K. (2013) Targeting activated Akt with GDC-0068, a novel selective Akt inhibitor that is efficacious in multiple tumor models. Clin. Cancer Res., 19, 1760-1772.

170. Dumble, M., Crouthamel, M.C., Zhang, S.Y., Schaber, M., Levy, D., Robell, K., Liu, Q., Figueroa, D.J., Minthorn, E.A., Seefeld, M.A., Rouse, M.B., Rabindran, S.K., Heerding, D.A. and Kumar, R. (2014) Discovery of novel AKT inhibitors with enhanced anti-tumor effects in combination with the MEK inhibitor. PLOS ONE, 9, e100880.

171. Hirai, H., Sootome, H., Nakatsuru, Y., Miyama, K., Taguchi, S., Tsujioka, K., Ueno, Y., Hatch, H., Majumder, P.K., Pan, B.S. and Kotani, H. (2010) MK-2206, an allosteric Akt inhibitor, enhances antitumor efficacy by standard chemotherapeutic agents or molecular targeted drugs in vitro and in vivo. Mol. Cancer Ther., 9, 1956-1967.

172. Chen, X., Qian, Y. and Wu, S. (2015) The Warburg effect: evolving interpretations of an established concept. Free Radic. Biol. Med., 79, 253-263. 